\title{
Semiconducting Metal Oxides Nanocomposites for Enhanced Detection of Explosive Vapors
}

\author{
Andrea Marchisio and Jean-Marc Tulliani * \\ Department of Applied Science and Technology, INSTM Research Unit PoliTO, Politecnico di Torino, \\ Corso Duca degli Abruzzi 24, 10129 Torino, Italy; andrea.marchisio@polito.it \\ * Correspondence: jeanmarc.tulliani@polito.it; Tel.: +39-(0)11-090-4700
}

Received: 15 May 2018; Accepted: 21 June 2018; Published: 25 June 2018

\begin{abstract}
In recent years, the detection of ultratraces of nitroaromatic compounds (NACs), such as 2,4,6-trinitrotoluene (TNT), has gained considerable attention due to associated problems related to environment, security against terrorists and health. The principle of NACs detection is simple since any explosive emits a rather small, but detectable number of molecules. Thus, numerous detection techniques have been developed throughout the years, but their common limitations are rather large sizes and weights, high power consumption, unreliable detection with false alarms, insufficient sensitivity and/or chemical selectivity, and hyper-sensitivity to mechanical influences associated with very high price. Thus, there is a strong need of cheap, rapid, sensitive, and simple analytical methods for the detection and monitoring of these explosives in air. Semiconducting metal oxides (SMOs) allow the preparation of gas sensors able to partially or totally overcome these drawbacks, and this paper aims to shortly review the most recent SMOs nanocomposites able to sense explosives.
\end{abstract}

Keywords: semiconducting metal oxide; gas sensor; doping; nanocomposite; explosives detection

\section{Introduction}

In recent years, the detection of ultratraces of nitroaromatic compounds (NACs), such as 2,4,6-trinitrotoluene (TNT), has gained considerable attention due to environmental, anti-terrorist security, and health-related problems associated with NACs [1]. In fact, NACs are toxic compounds able to cause severe health concerns in both animals and humans, leading to anemia, abnormal liver function, cataract development, and skin irritation $[2,3]$.

The principle of NACs detection is simple since any explosive emits a rather small, but detectable number of molecules [4]. Based on the concentration in air at the equilibrium at a certain temperature, explosives can be divided into three groups: high, medium, and low vapor pressure, as illustrated in Figure $1[5]$.

Triacetone triperoxide (TATP), ethylene glycol dinitrate (EGDN), 2,3-dimethyl-2,3-dinitrobutane (DMNB, a detection taggant for explosives), nitroglycerin (NG), and 2,4-dinitrotoluene (DNT) present a high vapor pressure. These explosives have equilibrium vapor concentrations in air in the ratio of about one part per million (1 ppm) [5-7]. Medium vapor pressure explosives have equilibrium vapor concentrations in air near one part per billion $(1 \mathrm{ppb})$, while low vapor pressure explosives have equilibrium vapor concentrations of one part per trillion (1 ppt). The medium vapor pressure group includes TNT (2,4,6-trinitrotoluene) and ammonium nitrate $\left(\mathrm{NH}_{4} \mathrm{NO}_{3}\right)$ [5-7]. The low vapor pressure group includes HMX (octogen), RDX (Research Department Explosive, hexogen or cyclonite), and PETN (pentaerythritoltetranitrate) [5-7]. RDX is 1000 times less volatile than 2,4,6-trinitrotoluene (TNT), corresponding to a parts-per-trillion vapor pressure under ambient conditions. Thus, compared to other explosives, trace detection of RDX is highly challenging [8]. The vapor pressure value concerns pure materials; for mixtures containing these explosives, the vapor pressure may be even lower [5]. 


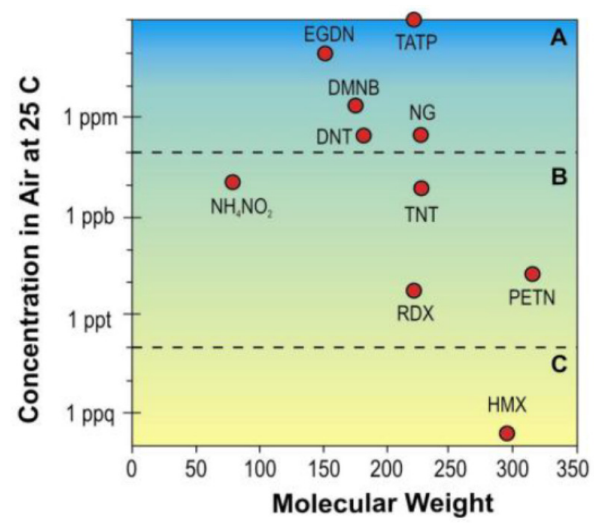

Figure 1. Room temperature vapor concentration of explosives (A, B, and C-high, medium, and low, respectively) [5].

Apart from nitro-based explosives, usually indicated as military explosives, homemade explosives, also referred to as improvised explosives (IEs), are produced widely by many terrorist groups throughout the world. Ammonium nitrate-fuel oil (ANFO) and urea nitrate (UNi) are two main kinds of IEs [9]. UNi can be transformed into nitro-urea $\left(\mathrm{NH}_{2} \mathrm{CONH}-\mathrm{NO}_{2}\right)$, a more powerful explosive, through a dehydration process [9]. The detection of IEs (ANFO, UNi, and nitro-urea) can be achieved by the indirect detection of their raw materials, for example, AN and urea [9].

Numerous detection techniques have been developed throughout the years, but their common limitations are rather large sizes and weights, high power consumption, unreliable detection with false alarms, insufficient sensitivity and/or chemical selectivity, and hyper-sensitivity to mechanical influences associated with very high price [1]. Thus, there is a strong need of cheap, rapid, sensitive, and simple analytical methods for the detection and monitoring of these explosives in air.

Table 1 illustrates that explosives' melting points are generally below $200{ }^{\circ} \mathrm{C}$, while boiling points are in the range $150-300^{\circ} \mathrm{C}$ [10]. Table 1 also indicates that boiling of explosives often leads to molecular decomposition. Once vaporized, the solids decompose into individual molecules, which then further decompose into smaller fragments. Experimentally, it was found that all explosives produce a cloud of reaction products made of nitrogen dioxide $\left(\mathrm{NO}_{2}\right)$, nitric oxide $(\mathrm{NO})$, ammonia $\left(\mathrm{NH}_{3}\right)$, hydrogen $\left(\mathrm{H}_{2}\right)$, carbon monoxide $(\mathrm{CO})$, carbon dioxide $\left(\mathrm{CO}_{2}\right)$, nitrogen $\left(\mathrm{N}_{2}\right)$, oxygen $\left(\mathrm{O}_{2}\right)$ and methane $\left(\mathrm{CH}_{4}\right)$ [10]. Among those, $\mathrm{NO}_{2}$ is the compound that is most easily detected at low concentrations and with relative selectivity using solid state gas sensors [10] because of its high electron affinity. This feature allows it to be set aside from most other gases in the ambient air (Table 2) and enables it to extract in a very efficient way conduction electrons from semiconductor materials [10].

The electron affinity (Ea) of an element is the energy liberated when an atom in the gas phase captures an electron. If electron affinity is negative, this means that an external energy is necessary to the atom to capture an electron [11]. The most abundant molecule in air having a positive electron affinity is oxygen (Ea of about $0.5 \mathrm{eV}$ ); thus, if free electrons are available, ions $\mathrm{O}_{2}^{-}$form spontaneously (Equation (1)) in clean ambient air:

$$
\mathrm{O}_{2}+\mathrm{e}^{-} \rightarrow \mathrm{O}_{2}^{-},
$$

In the case air is contaminated with $\mathrm{NO}_{2}$ molecules (Ea of about $2.3 \mathrm{eV}$ ) or $\mathrm{O}_{3}$ (Ea of about $2.1 \mathrm{eV}$ ), electrons initially captured by $\mathrm{O}_{2}$ molecules are spontaneously transferred (Equations (2) and (3)):

$$
\begin{gathered}
\mathrm{NO}_{2}+\mathrm{O}_{2}^{-} \rightarrow \mathrm{NO}_{2}^{-}+\mathrm{O}_{2}, \\
\mathrm{O}_{3}+\mathrm{O}_{2}^{-} \rightarrow \mathrm{O}_{3}^{-}+\mathrm{O}_{2},
\end{gathered}
$$


Table 1. Theoretical estimation of electron affinity of some important explosives [10].

\begin{tabular}{ccccccc}
\hline Name & $\begin{array}{c}\text { Aggregate } \\
\text { Form }\end{array}$ & Ea (eV) & $\begin{array}{c}\text { Vapor Pressure at } \\
\mathbf{2 5}{ }^{\circ} \mathbf{C}(\mathbf{p p b})\end{array}$ & $\begin{array}{c}\text { Melting } \\
\text { Point }\left({ }^{\circ} \mathbf{C}\right)\end{array}$ & $\begin{array}{c}\text { Boiling } \\
\text { Point }\left({ }^{\circ} \mathbf{C}\right)\end{array}$ & Product Gas \\
\hline TNT & Solid & $\sim 2.3$ & 9.55 & 80 & $\begin{array}{c}295 \\
\text { (igniting) }\end{array}$ & $\mathrm{NO}_{2}$ \\
RDX & Solid & $\sim 1.2$ & 0.006 & 205 & 235 & $\mathrm{NO}_{2}$ \\
PETN & Solid & $\sim 1.6$ & 0.18 & 141 & 150 & $\mathrm{NO}_{2}$ \\
AN & Solid & 3.58 & 12.3 & 170 & 210 & $\mathrm{NO}_{2}$ \\
UNi & Solid & $\sim 3.7$ & 0.009 & 163 & unknown & $\mathrm{NO}_{2}$ \\
\hline
\end{tabular}

Table 2. Electron affinity of $\mathrm{NO}_{2}$ relative to other molecular constituents of ambient air [10].

\begin{tabular}{ccc}
\hline Gas & Name & Ea (eV) \\
\hline $\mathbf{N}_{2}$ & Nitrogen & -0.72 \\
$\mathbf{O}_{2}$ & Oxygen & 0.448 \\
$\mathbf{H}_{2} \mathbf{O}$ & Water vapor & negative \\
$\mathrm{CO}_{2}$ & Carbon dioxide & -0.6 \\
$\mathbf{H}_{2}, \mathbf{H C}$ & Hydrogen, most hydrocarbons & negative \\
$\mathrm{NO}_{2}$ & Nitrogen dioxide & 2.273 \\
$\mathrm{O}_{3}$ & Ozone & 2.103 \\
\hline
\end{tabular}

As most explosives either contain $\mathrm{NO}_{2}$ or $\mathrm{NO}_{3}^{-}$side groups (Figure 2), these materials also present high electron affinities (Table 1). Once vaporized, explosives molecules can therefore easily take up negative charge from $\mathrm{O}_{2}^{-}$ions, thus forming negatively-charged analyte ions, which can then be easily analyzed with regard to their ion mass (this process is extensively used in the IMS (Ion Mobility Spectroscopy) detection of explosives, drugs, and chemical weapons in airports [10].

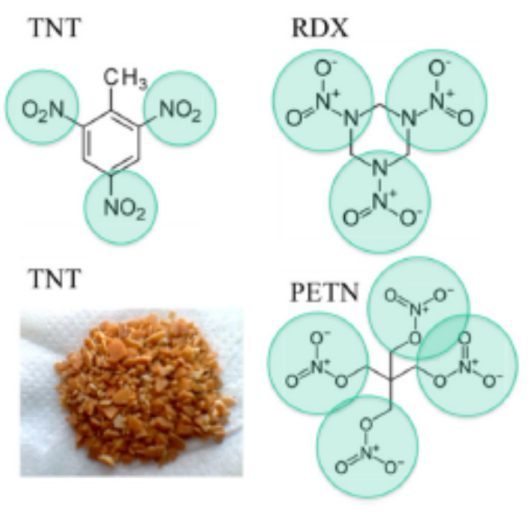

(a)

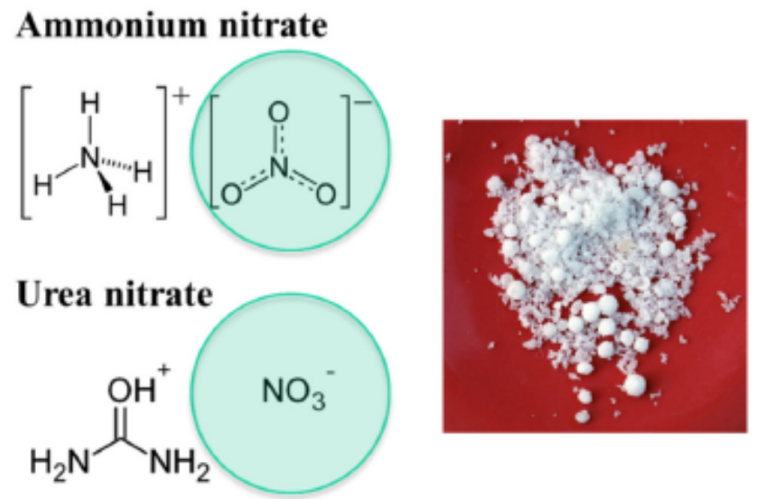

(b)

Figure 2. Molecular structure of some explosives: (a) military and (b) improvised ones. All compounds contain strongly electron-attracting NOx side groups (highlighted by green circles) [10].

Semiconductor metal oxides (SMOs) are able to sense gas based on the variation of their electrical properties. SMOs can be divided into two groups according to the operating temperature which dictates the mechanism by which these materials work: the first group is made by materials which follow surface conductance effects (below $600{ }^{\circ} \mathrm{C}$ ), while the second one is constituted by materials which follow bulk conductance effects (above $700{ }^{\circ} \mathrm{C}$ ) [8]. At lower temperature, the bulk defect effect is slow and conductance change is due to the formation and removal of surface-adsorbed oxygen species. The bulk conductance materials respond to the changes in oxygen partial pressure in the upper temperature range $\left(>700^{\circ} \mathrm{C}\right)$ and show the equilibrium between atmosphere and bulk stoichiometry [12].

The gas-sensing mechanism of SMO sensors involves two major functions: receptor and transducer. The receptor function involves recognition of a target molecule in gas-solid interface, 
which leads to an electronic change in the surface of the SMOs $[13,14]$. Chemical properties of the surface oxygen of the SMO itself are responsible for the receptor function in a sensor [14], which can be modified when the oxide surface is loaded with noble metal or acidic or basic oxide particles. Then, change in receptor function induces a large change in sensitivity. Transducer function is responsible for converting the signal generated by chemical interaction on the oxide surface (change in work function) into an electrical signal. This function is governed by each boundary or neck between grains.

Conductometric (resistive) gas sensors have a very simple construction: they are made of two electrodes, a gas-sensitive layer, a dielectric substrate, and a heater to ensure the working temperature in the active region $[15,16]$. As mentioned above, the operating principle of such sensors is based on the conductivity change of semiconductor materials under the influence of the gas-environment [15].

Figure 3 depicts receptor and transducer functions as well as physicochemical and material properties involved for a $n$-type semiconductor gas sensor. On the surface of the grains, the adsorbed oxygen molecules extract electrons from the conduction band and trap the electrons at the surface as ions, which leads to a band bending. Thus, an electron-depleted layer is formed (also called space-charge layer). The space-charge region, being depleted of electrons, is more resistive than the bulk of the SMO. When the particle size (D) of the sensing film is close to or less than twice the thickness of the space-charge layer (L), the sensitivity of the sensor is increased [16-20]. The control of $\mathrm{L}$ by impurity doping can give rise to a great change of the sensor response (SR) even when $\mathrm{D}$ is the same: $\mathrm{Al}$ doping of $\mathrm{SnO}_{2}$ increases SR, while $\mathrm{Sb}$ doping of $\mathrm{SnO}_{2}$ decreases $\mathrm{SR}$, respect to pristine $\mathrm{SnO}_{2}[20]$.

The utility factor shown in Figure 3 concerns the attenuation of the response due to the diffusion and reaction of reactive target gases through the pores of the sensing film [19]. Experiments and simulations have shown that in order to achieve high sensitivity and fast response, SMOs should present: high gas permeability (large pore size), large surface area, small grain size, low degree of agglomeration, and optimal thickness [15].

It is now accepted that below $150^{\circ} \mathrm{C}$, oxygen is adsorbed in ionic form (ionosorbed) as $\mathrm{O}_{2}^{-}$and in the temperature range from $150{ }^{\circ} \mathrm{C}$ to $400{ }^{\circ} \mathrm{C}$ (usually, the operating temperature of SMOs gas sensors), it dissociates as $\mathrm{O}^{-}$. Above $400{ }^{\circ} \mathrm{C}$, formation of $\mathrm{O}^{2-}$ occurs $[14,16,17,20,21]$. The required electrons are extracted from SMO'sconduction band and trapped at the surface, leading to an electron-depleted layer, as already explained. The presence of negative surface charge leads to band-bending which generates a potential barrier at the surface of the grains (Figure 3). The height and depth of these barriers depend on the amount of charge on the surface and is correlated to the quantity and type of adsorbed oxygen ions. Neutral oxygen species such as physisorbed oxygen are assumed not to play any role in gas-sensing as well as lattice oxygen ions $[16,17,21,22]$.

In the case of a $n$-type semiconductor, the resistance of the gas sensor decreases when in contact with reducing gases or vapors because surface oxygen species are consumed to oxidize the target gas and release electrons in the conduction band. On the contrary, for a $p$-type SMO, the conductivity decreases in presence of a reducing gas. The oxygen adsorption, the formation of electrical core-shell structures (due to holes accumulation layer at the outer surface of grains and the insulating core formed after oxygen ions adsorption), the conduction mechanisms, the catalytic activities, and the interactions with humidity of $p$-type oxide semiconductors are far different from those of $n$-type oxide semiconductors. In $p$-type SMOs, conduction occurs preferentially along the hole-accumulation layer near the surface where oxygen anions are adsorbed [23]. Then, the concentration of holes in this hole-accumulation layer decreases when $p$-type oxide semiconductor gas sensors are exposed to reducing gases [23]. Generally, the gas response of $p$-type-oxide-semiconductor-based gas sensors (i.e., the relative change in sensor conductance/resistance when a sensor is exposed to a gas) is equal to the square root of that of $n$-type oxide semiconductor-based gas sensors whose morphologies are identical to the $p$-type-oxide-semiconductor-based gas sensors [24]. However, the responses of $p$-type oxide semiconductor gas sensors can be increased by using aliovalent materials (i.e., electronic 
sensitization), by catalytically promoting gas detection (i.e., chemical sensitization), and by decreasing the size of the nanostructure so that $p$-type oxide semiconductor gas sensors can be used for practical applications. Finally, the selectivity of $p$-type oxide semiconductor gas sensors can be further tuned by doping or loading of catalysts that can promote the reaction between the sensor and a specific gas [23].

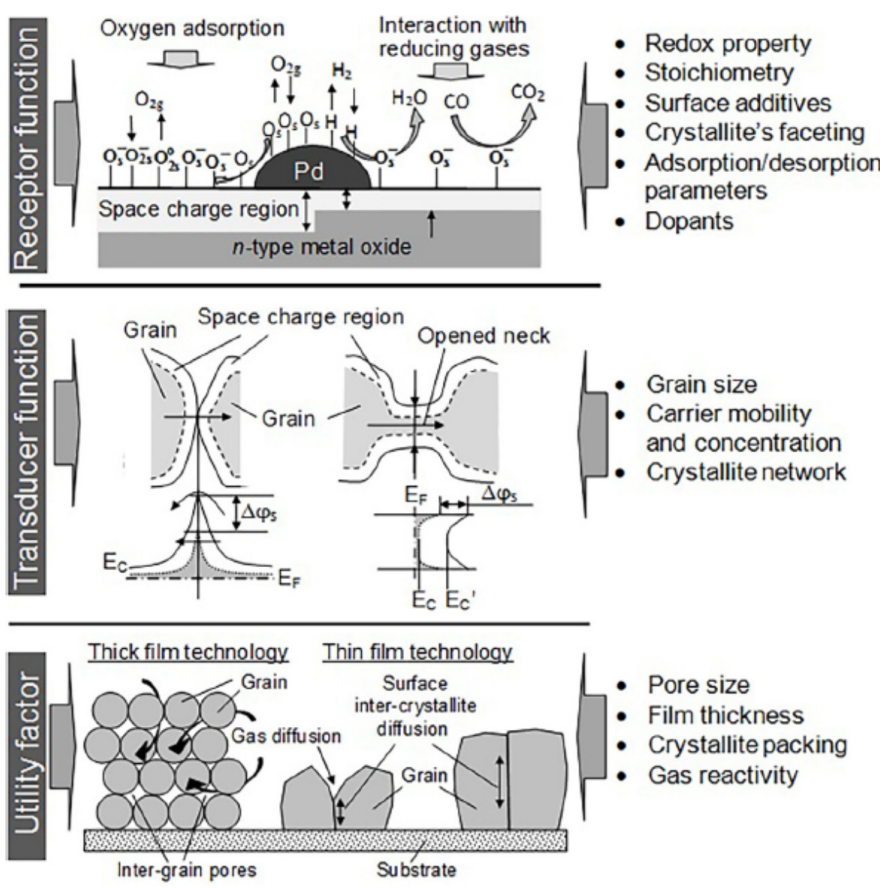

Figure 3. Receptor function, transducer function, and utility factor as well as physicochemical and material properties of SMOs. Reprinted with permission from Ref. [14]. ( $\Delta \varphi s$ : change in work function, $\mathrm{E}_{\mathrm{C}}$ : conduction level, $\mathrm{E}_{\mathrm{F}}$ : Fermi level).

In 1952, Brattain and Bardeen demonstrated the change of the semiconducting properties of germanium with a variation of the partial pressure of ozone or peroxide vapors in the surrounding atmosphere [25]. Later, Seiyama demonstrated the gas sensing effect on metal-oxides [26], and Taguchi brought metal-oxide semiconductor gas sensors to market in 1971, after founding in Osaka, in 1969, the company Figaro Engineering Inc., which is still today the largest manufacturer of semiconductor gas sensors world-wide.

The gas sensors market is expected to be valued at $\$ 1297.6$ million USD by 2023, growing at a compound annual growth rate (CAGR) of 6.83\% between 2017 and 2023 [27]. Actually, semiconductor oxide materials contribute more than $20 \%$ to market [28].

Commercial sensors should meet the following requirements:

- High response to the target agent,

- High selectivity to target gas in the presence of a mixture of gases,

- Fast and reversible interaction with analyte,

- Low sensitivity of the signal to a change in air humidity,

- Absence of long-term drift,

- Short time to operational status,

- Effective low-cost technology,

- High reproducibility,

- Uniform and strong binding to the surface of the substrate.

The first SMO gas sensors were based on $\mathrm{ZnO}$ and $\mathrm{SnO}_{2}$. Today, many different oxides have been investigated for manufacturing conductometric gas sensors (Table 3) [15,26]. 
Table 3. Some investigated SMOs in conductometric sensors, adapted from Ref. [15,29].

\begin{tabular}{|c|c|}
\hline Type of Metal Oxide & SMO \\
\hline Binary oxides & $\mathrm{ZnO}, \mathrm{SnO}_{2}, \mathrm{In}_{2} \mathrm{O}_{3}, \mathrm{WO}_{3}, \mathrm{TiO}_{2}, \mathrm{Ga}_{2} \mathrm{O}_{3}, \mathrm{Fe}_{2} \mathrm{O}_{3}, \mathrm{CuO}, \mathrm{NiO}, \mathrm{ZrO}_{2}, \mathrm{Co}_{3} \mathrm{O}_{4}, \mathrm{Cr}_{2} \mathrm{O}_{3}, \mathrm{Mn}_{3} \mathrm{O}_{4}$ \\
\hline Ternary oxides and solid solutions & $\begin{array}{l}\mathrm{CdIn}_{2} \mathrm{O}_{4}, \mathrm{Cr}_{2-\mathrm{x}} \mathrm{Ti}_{\mathrm{x}} \mathrm{O}_{3}, \mathrm{NiTa}_{2} \mathrm{O}_{6}, \mathrm{CoTa}_{2} \mathrm{O}_{6}, \mathrm{CuTa}_{2} \mathrm{O}_{6}, \mathrm{BaSnO}_{3}, \mathrm{LaFeO}_{3}, \mathrm{CdFe}_{2} \mathrm{O}_{4}, \mathrm{Bi}_{2} \mathrm{Sn}_{2} \mathrm{O}_{7}, \\
\mathrm{Bi}_{\mathrm{x}} \mathrm{Mo}_{\mathrm{y}} \mathrm{O}_{2}, \mathrm{Sn}_{1-\mathrm{x}} \mathrm{Fe}_{\mathrm{x}} \mathrm{O}_{\mathrm{y}}, \mathrm{NiFe}_{2} \mathrm{O}_{4}, \mathrm{CaFe}_{2} \mathrm{O}_{4}, \mathrm{ZnFe} \mathrm{O}_{4} ; \mathrm{SnO}_{2}-\mathrm{Fe}_{2} \mathrm{O}_{3}, \mathrm{In}_{2} \mathrm{O}_{3}-\mathrm{Fe}_{2} \mathrm{O}_{3}, \\
\mathrm{SnO}_{2}-\mathrm{CuO}, \mathrm{SnO}_{2}-\mathrm{AgOO}_{\mathrm{x}}, \mathrm{In}_{2} \mathrm{O}_{3}-\mathrm{Ga}_{2} \mathrm{O}_{3} ; \mathrm{TiO}_{2}-\mathrm{NiO}_{2} \mathrm{TiO}_{2}-\mathrm{V}_{2} \mathrm{O}_{5} ; \mathrm{ZnO}-\mathrm{ZnOO}_{2} \mathrm{SnO}_{2}-\mathrm{SiO}_{2}\end{array}$ \\
\hline More complex oxides & $\begin{array}{l}\mathrm{Li}-\mathrm{SmFe}_{2} \mathrm{O}_{4}, \mathrm{YBa}_{2} \mathrm{Cu}_{3} \mathrm{O}_{7-\delta}, \mathrm{Ni}_{0.99} \mathrm{Co}_{0.01} \mathrm{M}_{0.01} \mathrm{Fe}_{1.99} \mathrm{O}_{4}, \mathrm{BaSn}_{0.95} \mathrm{Zr}_{0.05} \mathrm{O}_{3}, \\
\mathrm{Na}_{0.1} \mathrm{Nb}_{0.1} \mathrm{~W}_{0.8} \mathrm{O}_{3}, \mathrm{CS}_{4} \mathrm{SiW}_{12} \mathrm{O}_{40}, \mathrm{CoMn}_{0.65} \mathrm{Fe}_{1.35} \mathrm{O}_{4}, \mathrm{BaTiO}_{3}-\mathrm{CuO}_{-}-\mathrm{La}_{2} \mathrm{O}_{3} ; \\
\mathrm{In}_{2} \mathrm{O}_{3}-\mathrm{SnO}_{2}-\mathrm{TiO}_{2} ; \mathrm{In}_{2} \mathrm{O}_{3}-\mathrm{ZnO}-\mathrm{SnO}_{2}\end{array}$ \\
\hline
\end{tabular}

It was experimentally verified, and it became a rule, that the higher the operating temperature is, the larger should be the band gap $\left(\mathrm{E}_{\mathrm{g}}\right)$ : the optimal band gap must be larger than $2.5 \mathrm{eV}$ for solid-state gas sensors working above $300{ }^{\circ} \mathrm{C}$. This requirement is satisfied by most SMOs. On the contrary, for sensors working at ambient temperature, $\mathrm{E}_{\mathrm{g}}$ can be considerably smaller, and this may be even an advantage [30]. However, it has to be underlined that the ability to operate at higher temperatures is an important advantage of solid-state gas sensors, because this considerably reduces the influence of water vapor on gas-sensing characteristics: the lower the operating temperature is, the greater is the sensitivity of the sensors to air humidity [31].

As the sensing material in conductometric gas sensors should be relatively conductive, the concentration of point defects in the SMOs should be rather high: it was experimentally demonstrated that the optimum lies in the range of $10^{17}-10^{19} \mathrm{~cm}^{-3}$, which corresponds to a conductivity of $10^{-2}-10^{1} \mathrm{Sm} / \mathrm{cm}$. On the contrary, a too high concentration of point defects and, as a consequence, a high electroconductivity or low resistivity, reduces the influence of the surface on the bulk concentration of charge carriers in the grains and hinders the effects on the surface. A too low concentration of free charge carriers $\left(n<10^{16} \mathrm{~cm}^{-3}\right.$, i.e., $\left.\sigma<10^{-4}-10^{-5} \mathrm{Sm} / \mathrm{cm}\right)$ is obviously also not acceptable [15].

As previously illustrated, conductometric sensors are based on processes occurring on the surface of the metal oxide and relating to adsorption-desorption phenomena and catalytic reactions. Unfortunately, in many cases, it is not known which crystallographic plane is optimal for gas-sensitive effects: we only know that these properties may be controlled through a change of the surface stoichiometry of the metal oxides by using various processing methods, or via the surface modification of metal oxides by catalytically active additives, such as noble or transition metals. However, the choice of optimal working conditions is empirical in nature, and often, the conditions found during such optimization are specific for the target gas and the technology selected for the synthesis and modification of the SMO [15]. However, studies have shown that the crystallographic structure of the metal oxides does not play a fundamental role: SMOs used in gas-sensing applications may have a cubic, hexagonal, orthorhombic, or tetragonal structure [15].

SMO gas sensors are robust and inexpensive; however, they currently lack sensitivity and selectivity to detect low vapor pressure explosives [32]. Introduction of additives into base metal oxides can change their features, such as, for example, the concentration of charge carriers, chemical and physical properties of the metal oxide matrix, electronic and physical-chemical properties of the surface (energetic spectra of surface states, energy of adsorption and desorption, sticking coefficients, etc.), surface potential and intercrystallite barriers, phase composition, sizes of crystallites, and others also [33,34]. Heterojunctions can increase SMOs' sensitivity and are based on two different metal oxides admixed or layered together $(p-n, n-n$ and $p$ - $p$ diodes made from a $p$ - and a $n$-type semiconductor) $[32,35,36]$.

The effect of the addition of metallic particles on the gas-sensing properties of SMOs has been widely studied for decades [33,37]. The influence of metallic particles addition has been classified as chemical or electronic according to two basic sensitization mechanisms. In the electronic mechanism, the reaction with the gas molecules takes place on the surface of the introduced clusters and not in the $\mathrm{SMO}$. These clusters change their charge state, leading to a variation of the surface barrier height and 
producing a conductance change in the metal oxide. In this case, the base semiconductor has only a transducer role of the changes induced in the metallic particles by their interaction with the target gas. In the chemical mechanism, the metal oxide itself acts as a chemical catalyst: the role of the additive is to increase the reaction rate of the gas molecules, which are firstly adsorbed on the metallic cluster and, later, moved to the oxide surface. This process is the so-called spill-over process. Among metallic surface additives, silver is typically considered to be related with an electronic mechanism, whereas palladium, gold, and platinum are expected to lead to the chemical one $[18,33,37,38]$. There is an optimum concentration for catalytically active modifiers at which their effect is maximal: in the case of nanocrystalline $\mathrm{SnO}_{2}$ modified with Pd, $\mathrm{Pt}$, and Au nanoparticles, this concentration is 0.2 to $3 \mathrm{wt} \%$ [39]. Upon exceeding the optimum impurity concentration, the effect decreases for various reasons: the catalytic conversion of the targeted gas on the modifier clusters without involving the semiconductor matrix, the decreasing portion of the semiconductor oxide-free surface and concentration of the adsorbed oxygen species on it, or the percolation of the noble metal clusters [39].

Among the different sensors features that can influence its response, it is now recognized that the lower the crystallite size is, the higher the response is [40]. On the contrary, the response time (the time needed by a sensor to achieve $90 \%$ of the total impedance change in the case of gas adsorption) and the recovery time (the time necessary to reach $90 \%$ of the total impedance variation in the case of gas desorption) are shortened by the decrease of the crystallite size [40]. However, it was also found that nanostructured films having a smaller crystallite size presented a stronger sensitivity to the air humidity of the surrounding atmosphere. This behavior was explained because the change of the shape from crystallites $(t>10 \mathrm{~nm})$ to spherulites $(t<7-10 \mathrm{~nm})$ is associated with an increased number of structural and electronic defects. The presence of a huge number of atomic steps and corners, typical of spherulite-type grains, could also be a reason favoring the interaction with water vapor [40]. Therefore, if the minimum sensitivity to air humidity and maximum stability of sensor parameters are required, the size of crystallites will be the result of a compromise between these two features [40]. In SMOs, formed by using thick-film technology (like, for example, screen-printing technique), the pore size is strongly correlated with the crystallite size. Then, the larger the crystallite size is, the larger is the pore size. This means that the requirement to increase the pore size for better gas permeability of the thick-film is in contradiction with the need to reduce the crystallite size for achieving a higher sensitivity [40].

Finally, a considerable contribution to the sensor signal is made by the acidic/basic and redox reactions that occur on the surface of the sensing material when interacting with the gas phase. The specificity or selectivity of these reactions is mainly determined by the nature of the available active sites on the surface [41]. Hydroxy groups, chemisorbed oxygen, and coordinatively unsaturated atoms can act as active sites on the oxide surface. The oxidation ability of the oxides is attributed to chemisorbed oxygen and variable valence metal atoms. In the second case, the efficiency of the charge transfer from the matrix to an active cation plays a great role too [41]. Experiment has shown that the use of metal oxide nanocomposites also allows significant increases in the stability of the grain size during annealing, limiting grain growth. Grain growth due to high working temperatures is one of the reasons for the instability of gas sensor parameters during their service life [14].

Thus, this paper aims at shortly reviewing the most recent SMOs nanocomposites able to sense explosives.

\section{Most Promising Semiconducting Metal Oxides for Explosive Vapor Detection}

\subsection{Zinc Oxide Composites}

$\mathrm{ZnO}$ is a $n$-type semiconductor with a wide band gap of $3.37 \mathrm{eV}$, high electron mobility, photoelectric response, and excellent chemical and thermal stability [42]. Therefore, zinc oxide has been extensively studied to detect vapors and gases such as ethanol, urea, TNT, and many more. Promising results with regards to explosives detection are described in ref. [9] where $\mathrm{ZnO}$ 
nanopowders doped with $\mathrm{Fe}, \mathrm{Co}$, and Ni were prepared. In this work, $50 \mathrm{~mL}$ of a solution of $\mathrm{Zn}\left(\mathrm{NO}_{3}\right)_{2}$ $0.1 \mathrm{M}$ in ethanol and $0.005 \mathrm{M}$ of iron nitrate nonahidrate, cobalt nitrate tetrahydrate, or nickel acetate tetrahydrate were mixed with $50 \mathrm{~mL}$ of a $0.15 \mathrm{M}$ solution in ethanol of $\mathrm{LiOH} . \mathrm{H}_{2} \mathrm{O}$. Both solutions were kept in a fridge at $0{ }^{\circ} \mathrm{C}$ and their mixing was done in an ice bath for $2 \mathrm{~h}$. After precipitation, the solid residue was first washed in heptane, then in ethanol, repeatedly for 3 times. Finally, the powder was oven-dried at $60^{\circ} \mathrm{C}$ overnight. Then, several thermal treatments at $200^{\circ}, 400^{\circ}$, or $600{ }^{\circ} \mathrm{C}$ for $1 \mathrm{~h}$ were done (Figure 4 ). The sensors were produced by painting a paste obtained by dispersing the sensing material in ethanol (in a ratio of powder:ethanol equal to 4:1) over an alumina substrate with silver electrodes $200 \mu \mathrm{m}$-spaced. The sensors were tested with respect to ammonium nitrate, 2,4,6-trinitrotoluene, and purified after dissolution in ethanol, DNT, para-nitrotoluene (PNT), urea, picric acid (PA), and RDX. A fixed amount of explosive was placed in a closed glass container of 250 $\mathrm{mL}$ at room temperature and left for $48 \mathrm{~h}$ to ensure air saturation with explosive vapors before any measurement. The sensor response was determined according to Equation (4):

$$
\text { Response }(\%)=\frac{\left(R_{a}-R_{g}\right)}{R_{a}} \times 100,
$$

where $R_{a}$ and $R_{g}$ are the values of the sensor's resistance under air and under the explosive's vapor, respectively.

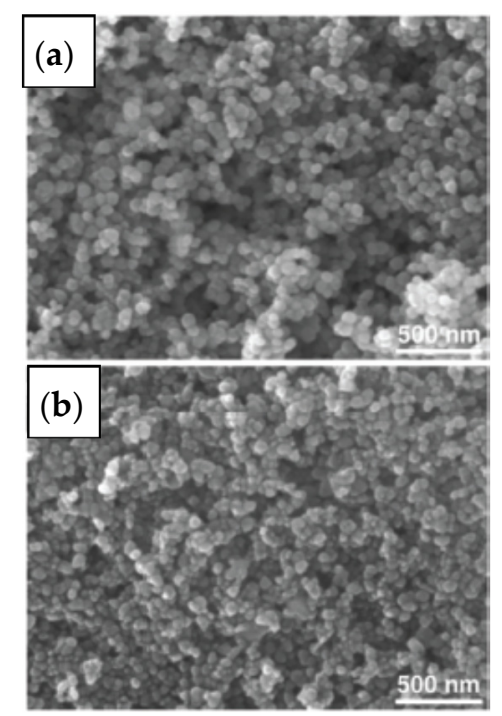

Figure 4. FESEM micrographs of heat treated at $400{ }^{\circ} \mathrm{C}$ for $1 \mathrm{~h} \mathrm{ZnO}$ powders doped with: (a) Co; (b) Ni. Reprinted with permission from Ref. [9].

Impressive results were obtained at room temperature, either with nitroaromatic compounds, or with improvised explosives (Figures 5 and 6). Moreover, response and recovery times of the sensors heated at $400{ }^{\circ} \mathrm{C}$ were very fast: 2 and $3 \mathrm{~s}$, respectively, for nickel-doped $\mathrm{ZnO}$ sensor in the presence of $4.9 \mathrm{ppt}$ of RDX. These results are due to the higher number of oxygen vacancies in the doped samples after the thermal treatment at $400{ }^{\circ} \mathrm{C}$, with respect to the powders heated at $200^{\circ} \mathrm{C}$ or $600{ }^{\circ} \mathrm{C}$. 

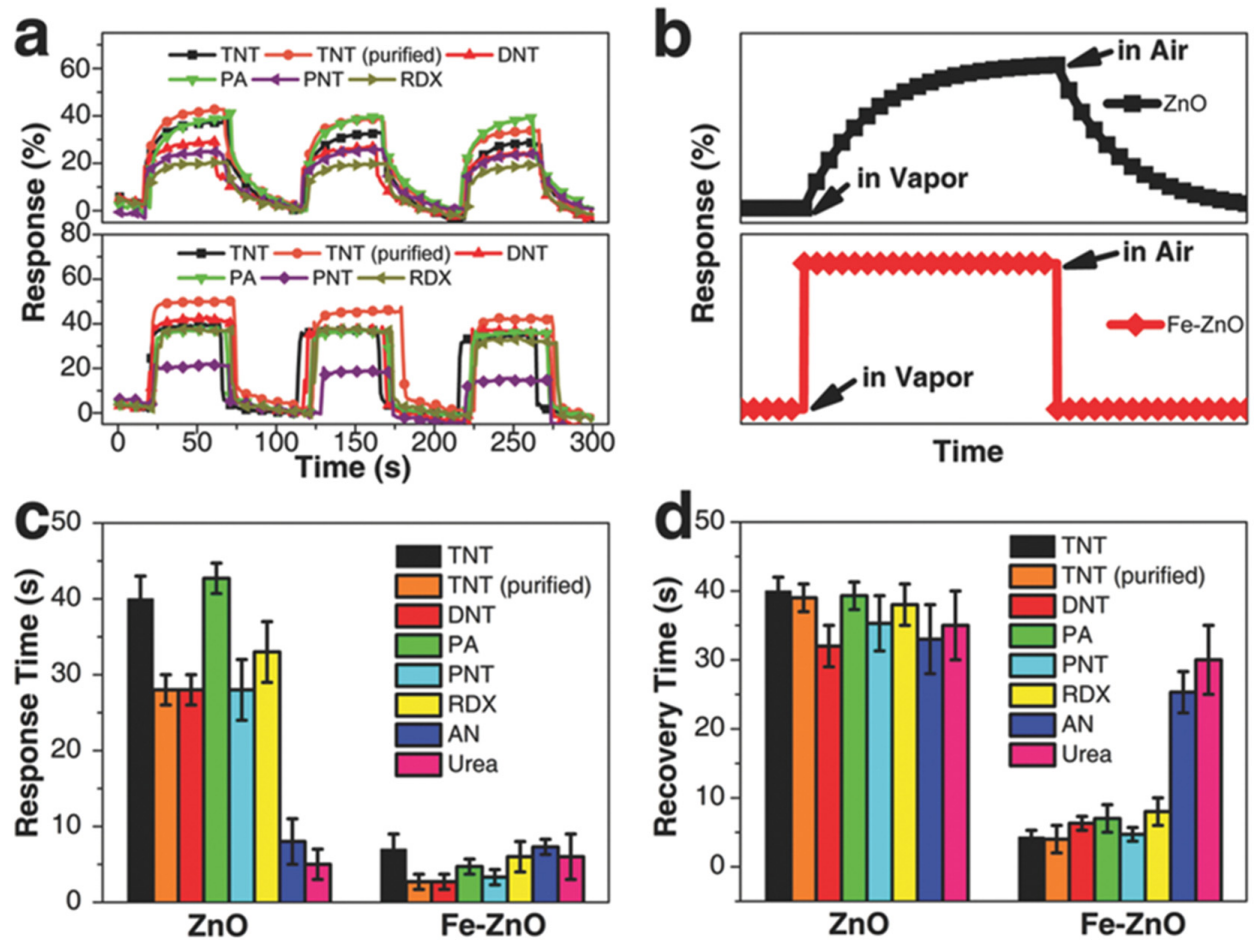

Figure 5. (a) Response of two sensors based on $\mathrm{ZnO}$ (up) and $\mathrm{Fe}-\mathrm{ZnO}$ (down) nanoparticles during three successive cycles of exposure to TNT, TNT (purified), DNT, PA, PNT, and RDX vapors $\left(25^{\circ} \mathrm{C}\right)$; (b) schematic diagram of the response changes of $\mathrm{ZnO}$ (up) and $\mathrm{Fe}-\mathrm{ZnO}$ (down) nanoparticle-based sensors; (c) response time and (d) recovery time of the two sensors based on $\mathrm{ZnO}$ and Fe- $\mathrm{ZnO}$ nanoparticles toward room-temperature saturated vapors of TNT, TNT (purified), DNT, PA, PNT, RDX, AN, and urea. Reprinted with permission from Ref. [9].
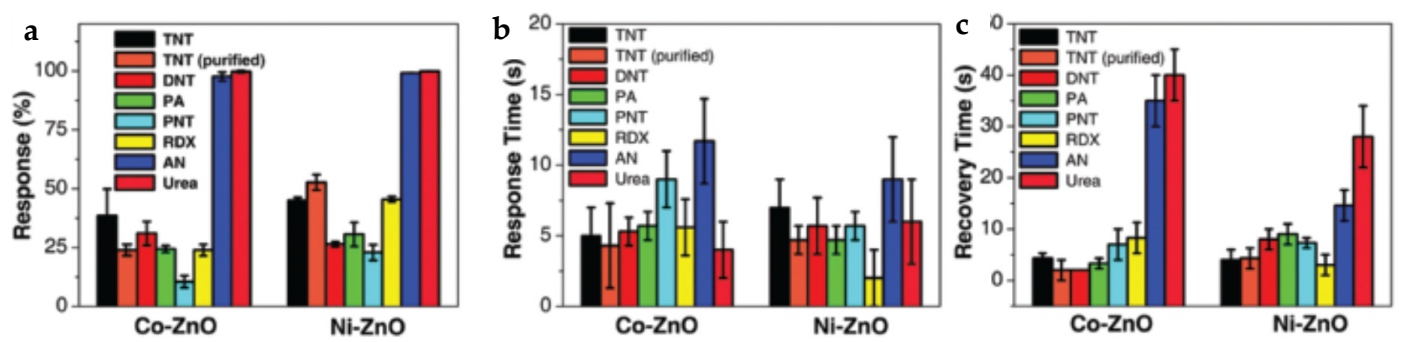

Figure 6. Sensor responses (a); response time (b); recovery time (c) of the two sensors based on Co- $\mathrm{ZnO}$ and Ni-ZnO nanoparticles toward room-temperature saturated vapors of TNT, TNT (purified), DNT, PA, PNT, RDX, AN, and urea. Reprinted with permission from Ref. [9].

Silica nanosprings $80 \mu \mathrm{m}$ thick were produced in about $15 \mathrm{~min}$ on gold-coated silica substrates in presence of a silica precursor [43]. Then, the springs were coated with $\mathrm{ZnO}$ nanoparticles by an atomic layer deposition (ALD) from a solution of zinc diethyl and deionized water at $175^{\circ} \mathrm{C}$ under 1 Torr of Ar. Each ALD cycle consists of a pulse of zinc diethyl, followed by argon flow up to a pressure of 2.5 Torr for $10 \mathrm{~s}$. Then, the cell is purged for $8 \mathrm{~s}$, and distilled water is injected for $300 \mathrm{~ms}$, prior to a new purge with a $20 \mathrm{~s}$ pulse of Ar. This cycle is repeated 150 times, leading to a uniform coating $75 \mathrm{~nm}$ thick. Finally, the ZnO-coated nanosprings were immersed in a solution of Pd acetylacetonate dissolved in ethanol (having a concentration of $1.95 \times 10^{-2} \mathrm{M}$ ), dried, and heat-treated at $500{ }^{\circ} \mathrm{C}$ for $15 \mathrm{~min}$ under a hydrogen and nitrogen flow to reduce the palladium precursor in metallic palladium having an average size of $2.4 \pm 1.3 \mathrm{~nm}$ (Figure 7). 


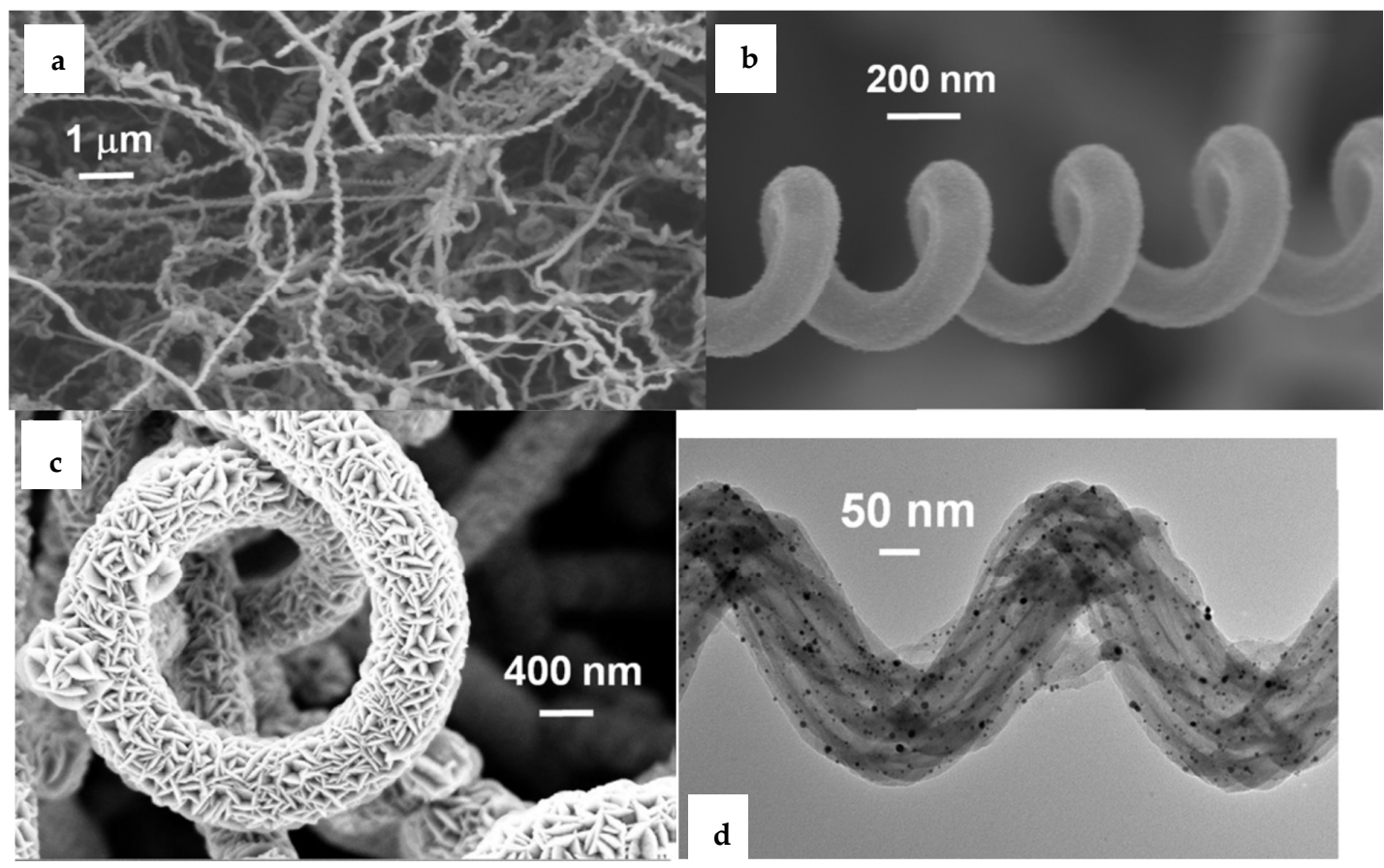

Figure 7. (a) FESEM micrographs of a silica nanospring, (b); SEM micrograph of a ZnO-coated nanospring (c); TEM micrograph of silica nanosprings, without $\mathrm{ZnO}$; (d) coated with Pd nanoparticles. Reprinted with permission from Ref. [43].

Sensors responses were determined by means of a sourcemeter (Keithley 2400, Keithley Instruments, Inc., Cleveland, OH, USA) between $100{ }^{\circ} \mathrm{C}$ and $500^{\circ} \mathrm{C}$. The best results were obtained at $400{ }^{\circ} \mathrm{C}$. The resistance value changed from some $\mathrm{k} \Omega$ to some $\mathrm{M} \Omega$ and from some $\mathrm{k} \Omega$ to some tens of $\mathrm{M} \Omega$, respectively, for an average $\mathrm{ZnO}$ crystallite size of $8 \mathrm{~nm}$ and $15 \mathrm{~nm}$. Explosives vapors were generated from the VaporJet ${ }^{\mathrm{TM}}$ system (MicroFab technologies Inc., Plano, TX, USA): drop-on-demand of the explosive solution (with a volume of 20-200 pL) were produced by a piezoelectric head on a heater which vaporizes them, creating a flow of gas sent to the sensors. Results obtained under few ppb of TATP and TNT (Figure 8) were encouraging and attributed to the catalytic decomposition of the vapors on the sensing material surface at the working temperature [43].
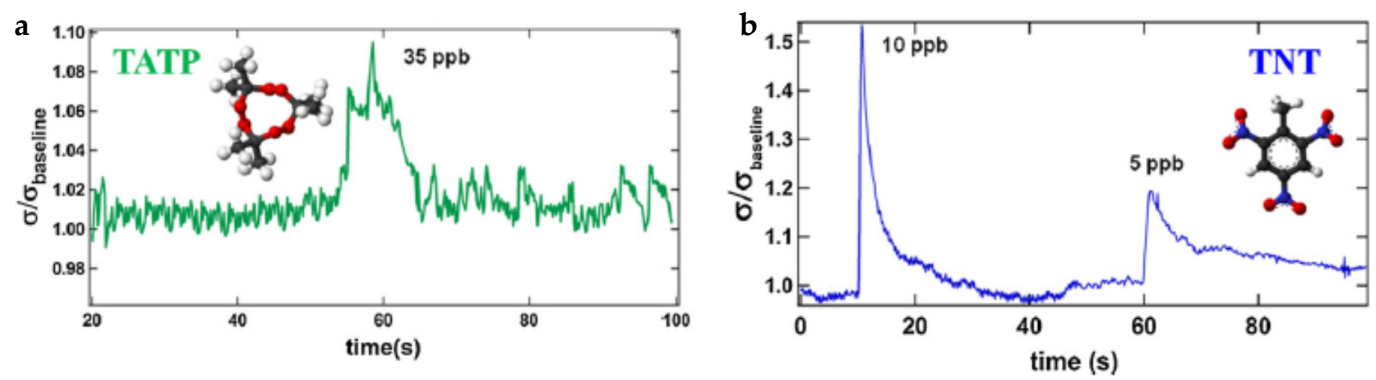

Figure 8. Relative change in conductance of a $\mathrm{Pd} / \mathrm{ZnO}$ nanospring sensor upon exposure (pulses of 0.1 $\mathrm{ms})$ to: TATP (35 ppb) (a); TNT (10 ppb and $5 \mathrm{ppb})(\mathbf{b})$. Reprinted with permission from Ref. [43].

Core-shell $\mathrm{ZnO}$ /reduced graphene oxide (rGO) structures were recently manufactured and tested on DNT, TNT e RDX vapors [44]. $20 \mathrm{mg}$ of graphene oxide (GO) were dispersed in $20 \mathrm{~mL}$ of dimethylformamide (DMF) and sonicated for $30 \mathrm{~min}$. In the meantime, four different amounts of $\mathrm{Zn}\left(\mathrm{CH}_{3} \mathrm{COO}\right)_{2} .2 \mathrm{H}_{2} \mathrm{O}$ were dissolved in $100 \mathrm{~mL}$ of DMF: $0.115 \mathrm{~g}, 0.23 \mathrm{~g}, 0.46 \mathrm{~g}$, and $069 \mathrm{~g}$, respectively, in the solution $\mathrm{N}^{\circ} 1, \mathrm{~N}^{\circ} 2, \mathrm{~N}^{\circ} 3$ and $\mathrm{N}^{\circ} 4$. Then, the GO solution was slowly added to the solution 
of zinc precursor under stirring, and the mixture was heated at $95{ }^{\circ} \mathrm{C}$ for $5 \mathrm{~h}$ in a closed vessel (hydrothermal synthesis). After centrifugation, a white-greyish product was obtained which was ethanol and water-washed several times before drying in an oven at $60^{\circ} \mathrm{C}$, and going through final calcination at $350{ }^{\circ} \mathrm{C}$ for $6 \mathrm{~h}$ (Figure 9). $\mathrm{ZnO}$ nanospheres synthesis followed the same process without GO addition. The sensing material was mixed in deionized water in a ratio 4:1 and manually ground in a mortar for $15 \mathrm{~min}$ to obtain a paste to be painted on a ceramic substrate with silver interdigitated 200- $\mu \mathrm{m}$-spaced electrodes. The sensors were tested with respect to 2,4,6-trinitrotoluene (TNT), DNT, para-nitrotoluene (PNT), picric acid (PA), and RDX. A certain amount of explosive was put in a $250 \mathrm{~mL}$ glass container at room temperature and left for $48 \mathrm{~h}$ to saturate air with vapors before any measurements. The sensor response was then determined according to Equation (5):

$$
\text { Response }(\%)=\frac{\left(I_{g}-I_{a}\right)}{I_{a}} \times 100,
$$

where $I_{a}$ and $I_{g}$ are the values of the current passing through the sensor under air and under the explosive's vapor.
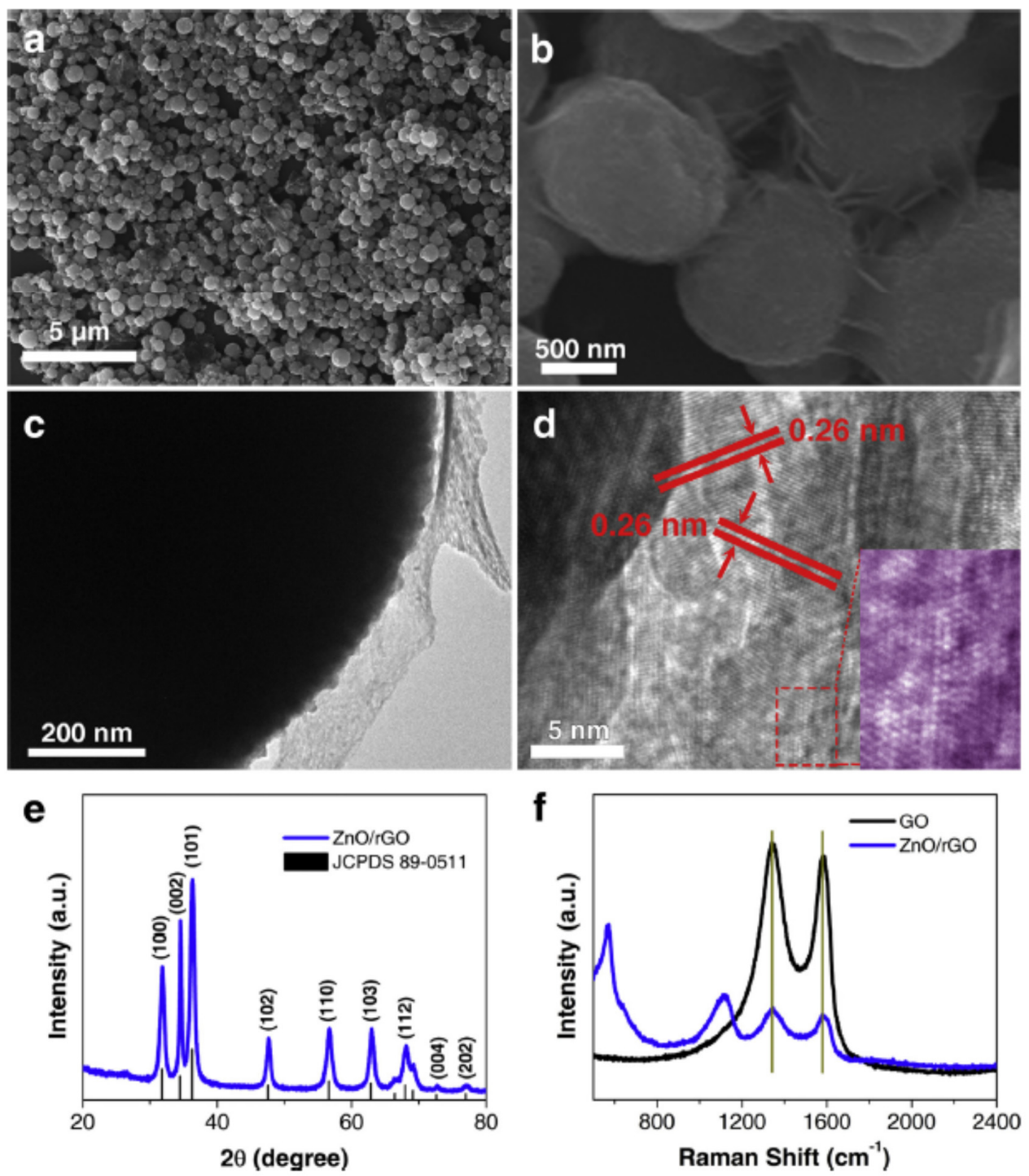

Figure 9. (a,b) ZnO/rGO micrographs: SEM; (c,d) TEM; X-ray diffraction pattern; (e) Raman spectrum of $\mathrm{ZnO} / \mathrm{rGO}$ powder (f). Reprinted with permission from Ref. [44]. 
I-V curves (Figure 10) present a typical nonlinear behavior, due to the formation of a Schottky junction between the core made of $\mathrm{ZnO}$ grains and the rGO shell. Moreover, sensors' response is negative on TNT, DNT, and RDX vapors exposure, while they are positive under PNT and PA vapors exposure (Figure 10). These results can be correlated with the ability of TNT, DNT, and RDX to easily withdraw electrons to the sensing material with respect to PNT and PA. Thus, $\mathrm{ZnO} / \mathrm{rGO}$ sensor response after exposure to saturated explosives' vapors were $-56.8 \%,-58.4 \%,+20.2 \%,-80 \%$, and $+16.3 \%$, respectively, for TNT, DNT, PNT, RDX, and PA. The sensitivity of the produced materials was excellent, keeping into consideration the vapor pressure of $9 \mathrm{ppb}$ for TNT, $411 \mathrm{ppb}$ for DNT, and of $4.9 \mathrm{ppt}$ for RDX. In addition, response and recovery times were very fast, in the order of some seconds (often $<5 \mathrm{~s}$ ) (Figure 10). Finally, among the different investigated compositions, the sensor deriving from the solution $\mathrm{N}^{\circ} 3$ gave the best results, while the pristine materials $(\mathrm{ZnO}$ and $\mathrm{rGO}$ ) did not present the same sensitivity as the $\mathrm{ZnO} / \mathrm{rGO}$ core/shell structures. These results demonstrated that sensors based on Schottky junction are excellent candidates for traces detection [44].
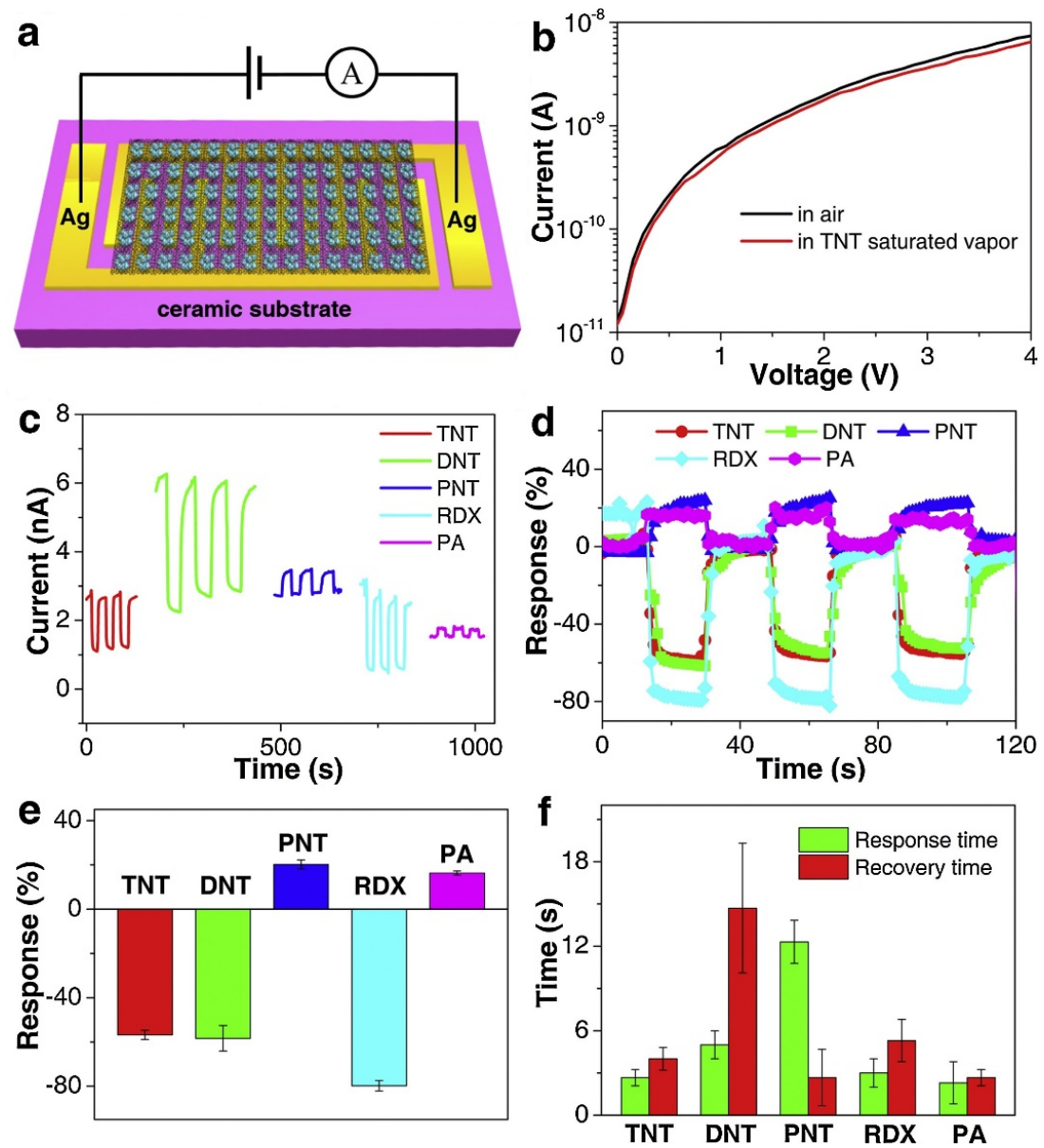

Figure 10. (a) Schematic view of the $\mathrm{ZnO} / \mathrm{rGO}$ core/shell junction-based sensor; (b) typical I-V curves upon exposure to air and TNT saturated vapor; (c) current changes; (d) responses of the sensor towards room-temperature saturated vapors of TNT, DNT, PNT, RDX, and PA; (e) response times; (f) recovery times. Reprinted with permission from Ref. [44].

Zinc oxide was also doped with $1 \% \mathrm{PdCl}_{2}, 1$ at $\% \mathrm{TiO}_{2}, 1$ at $\% \mathrm{WO}_{3}, 5$ at $\% \mathrm{~V}_{2} \mathrm{O}_{5}$ and 5 at $\% \mathrm{Sb}_{2} \mathrm{O}_{3}$ to detect 2,6-DNT, ammonium nitrate, picric acid (PA), and mining explosives (ME) (Table 4) [45]. The $\mathrm{ZnO}$ nanoparticles were produced by evaporation at high temperature and have a mean diameter of $35 \mathrm{~nm}$. The sensing materials were painted on alumina tubes with Pt electrodes and the samples were sintered at $650^{\circ} \mathrm{C}$ for $2 \mathrm{~h}$ after drying in air. 
The explosives were put in a sealed container equipped with a Pt-Rh heater applied with $3.5 \mathrm{~V}$ while the sensors were applied with $10 \mathrm{~V}$ (the working temperature is unfortunately not specified). Some measurements were performed with $4 \mathrm{mg}$ of explosive decomposed in a $60 \mathrm{~mL}$ glass flask from which a known volume of gas is sampled and injected in the chamber with the sensor to test $(3.34,10.0$, $16.67,50.0$ and $83.34 \mu \mathrm{g} / \mathrm{L}$ ) (Figure 11). When necessary, mass flows were used to dilute explosives' vapors (Figure 12).

The sensors' response was determined according Equation (6) for oxidizing gases:

$$
S=\frac{R_{a}}{R_{g}}
$$

and according to Equation (7) for reducing gases:

$$
S=\frac{R_{g}}{R_{a}}
$$

where $R_{a}$ and $R_{g}$ are the values of the sensor's resistance under air and under gas vapor, respectively. Sensors response to the mix of gases derived from the thermal decomposition of the explosives are shown in Figure 13.

The static test results under the concentrations of 3.34 and $83.34 \mu \mathrm{g} / \mathrm{L}$ were analyzed by means of discriminant functional analysis (DFA, Figure 14). Figure 14a shows that the response of the sensors can be separated into four groups when the concentration of explosives vapor is higher. On the contrary, when the concentration is lower, there is some overlapping of the responses (Figure 14b). In this latter case, the probability of recognizing an explosive is only $65.6 \%$, because of the low sensors' response. Finally, when the concentration of vapors is $15.4 \mu \mathrm{g} / \mathrm{L}$, the four explosives can be clearly distinguished. In conclusion, the sensors based on $\mathrm{WO}_{3}$-doped $\mathrm{ZnO}$ evidenced a good response to the three oxidizing gases (equal to 14, 8.5, and 7, respectively for $\mathrm{NH}_{4} \mathrm{NO}_{3}, \mathrm{ME}$, and PA at the concentration of $83.34 \mu \mathrm{g} / \mathrm{L}$ ). However, pure $\mathrm{ZnO}$ and $\mathrm{TiO}_{2}$-doped $\mathrm{ZnO}$ were better in 2,6-DNT (reducing gas) detection, showing a response of 2.5 and 3, respectively, at the concentration of $83.34 \mu \mathrm{g} / \mathrm{L}$ ).

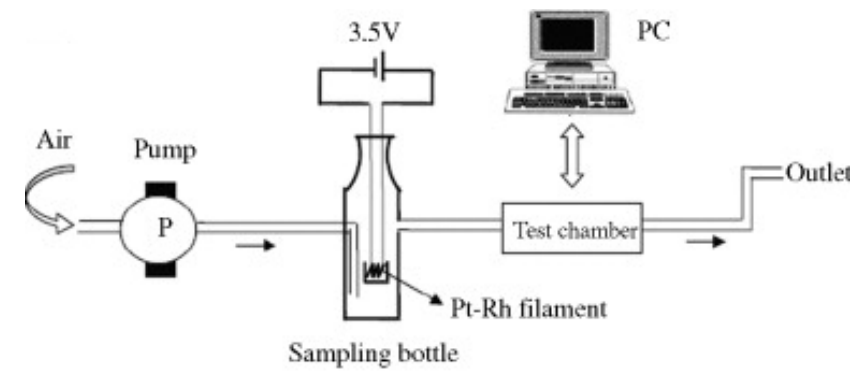

Figure 11. Static-state experimental setup. Reprinted with permission from Ref. [45].

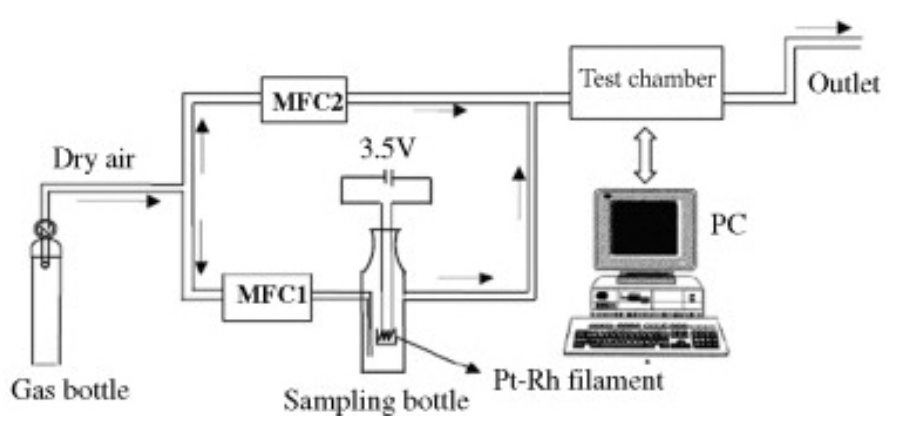

Figure 12. Dynamic sampling and low concentration experimental setup. Reprinted with permission from Ref. [45]. 

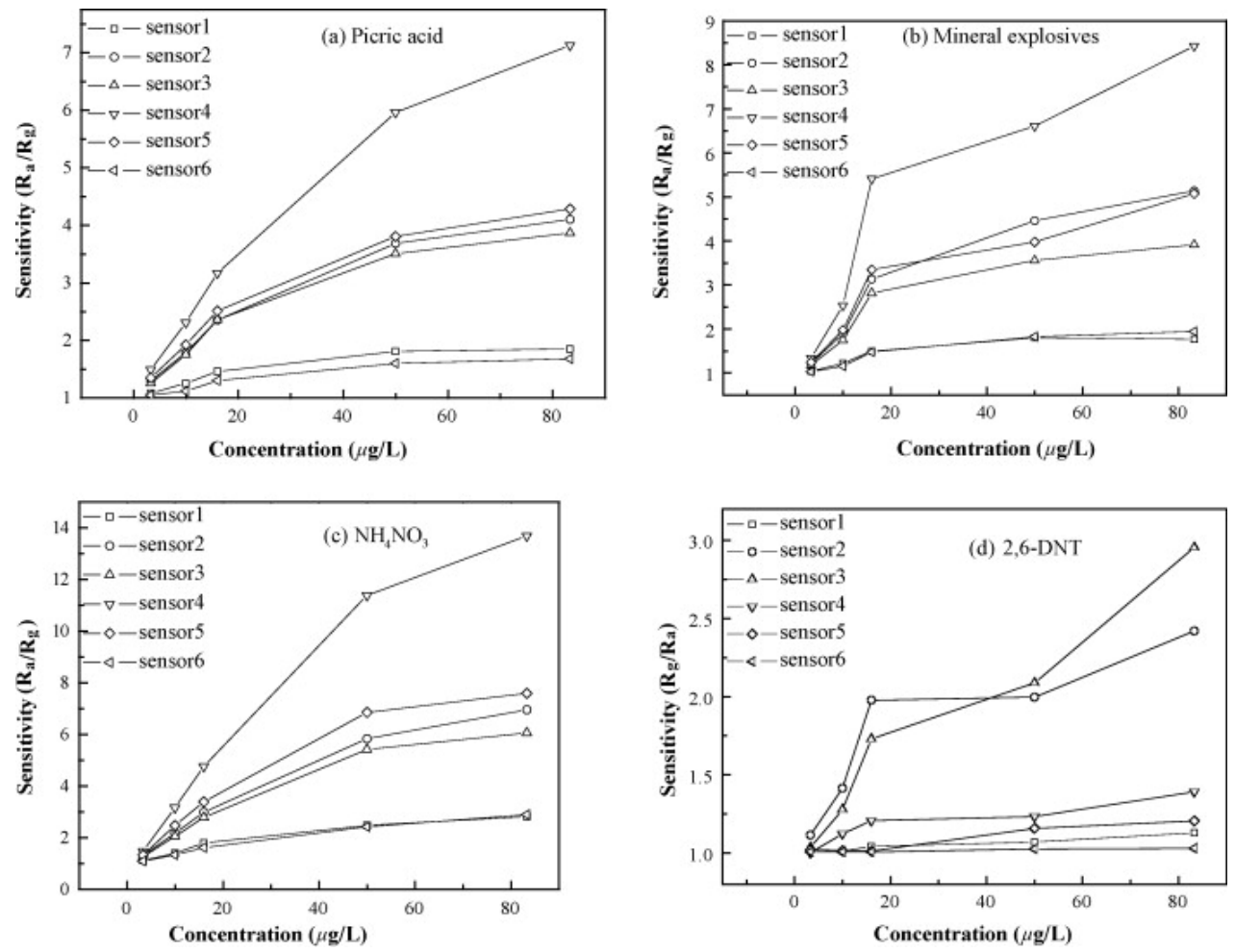

Figure 13. The sensitivity of the six sensors to various concentrations of the four explosives: picric acid (a); mineral explosives (b); $\mathrm{NH}_{4} \mathrm{NO}_{3}$ (c); 2,6-DNT (d). Reprinted with permission from Ref. [45].
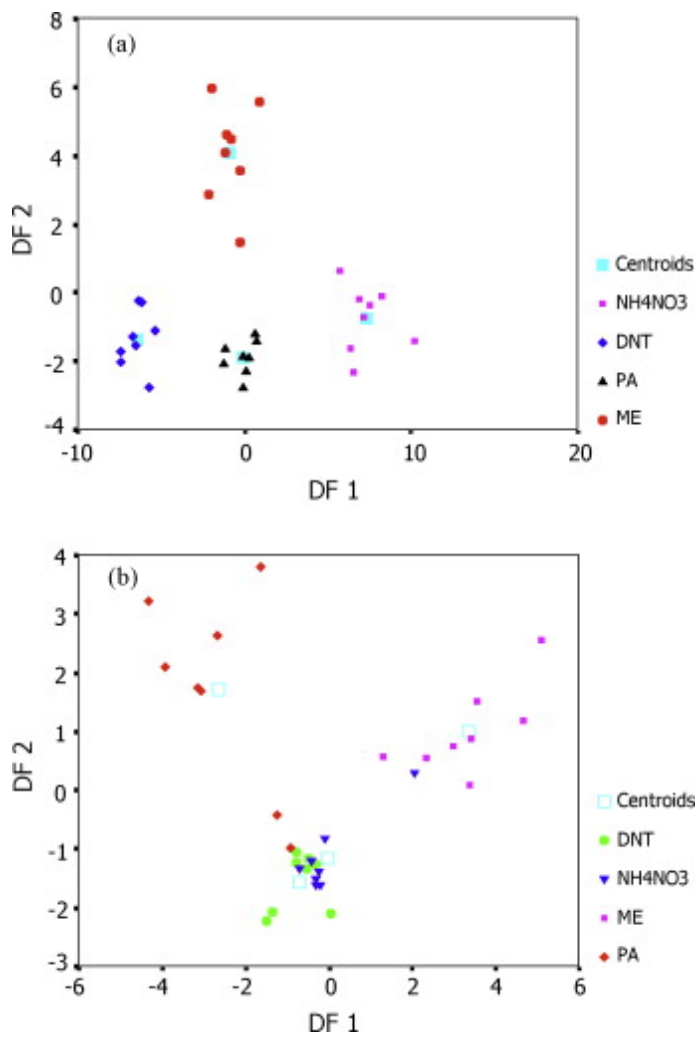

Figure 14. Discriminant functional analysis (DFA) results for static sampling experiments at the concentrations of: (a) $83.3 \mu \mathrm{g} / \mathrm{L}$; (b) $3.34 \mu \mathrm{g} / \mathrm{L}$. Reprinted with permission from Ref. [45]. 
Table 4. Investigated compositions [45].

\begin{tabular}{|c|c|c|}
\hline Sensor's Number & Components of Raw Material & $\mathrm{Ea}(\mathrm{eV})$ \\
\hline 1 & $\mathrm{Zn}\left(1 \% \mathrm{PdCl}_{2}\right)$ & $\begin{array}{l}\text { Prepared from } \mathrm{Zn} \text { nanoparticle flurry and then quick immersion of dry } \\
\text { film into } 1 \% \mathrm{PdCl}_{2} \text { solution and out. }\end{array}$ \\
\hline 2 & $\mathrm{Zn}$ & Prepared from Zn nanoparticle flurry. \\
\hline 3 & 1 at $\% \mathrm{TiO}_{2}+\mathrm{Zn}$ & $\begin{array}{l}\text { Prepared from mixture flurry of } \mathrm{TiO}_{2} \text { and } \mathrm{Zn} \text { nanoparticles with atomic } \\
\text { ratio Ti: } \mathrm{Zn} \text { of 1:99. }\end{array}$ \\
\hline 4 & $1 \mathrm{at} \% \mathrm{WO}_{3}+\mathrm{Zn}$ & $\begin{array}{l}\text { Prepared from mixture flurry of } \mathrm{WO}_{3} \text { and } \mathrm{Zn} \text { nanoparticles with atomic } \\
\text { ratio } \mathrm{W}: \mathrm{Zn} \text { of 1:99. }\end{array}$ \\
\hline 5 & 5 at $\% \mathrm{~V}_{2} \mathrm{O}_{5}+\mathrm{Zn}\left(1 \% \mathrm{PdCl}_{2}\right)$ & $\begin{array}{l}\text { Prepared from mixture flurry of } \mathrm{V}_{2} \mathrm{O}_{5} \text { and } \mathrm{Zn} \text { nanoparticles with } \\
\text { atomic ratio V: } \mathrm{Zn} \text { of } 5: 95 \text { and then quickly immersed into } 1 \% \mathrm{PdCl}_{2} \\
\text { solution and out. }\end{array}$ \\
\hline 6 & 5 at $\% \mathrm{Sb}_{2} \mathrm{O}_{3}+\mathrm{Zn}$ & $\begin{array}{l}\text { Prepared from mixture flurry of } \mathrm{Sb}_{2} \mathrm{O}_{3} \text { and } \mathrm{Zn} \text { nanoparticles with } \\
\text { atomic ratio } \mathrm{Sb}: \mathrm{Zn} \text { of 5:95. }\end{array}$ \\
\hline
\end{tabular}

\subsection{Zeolites and Metal Organic Frameworks (MOFs)}

Zeolites (H-Zeolite, Socony Mobil (ZSM-5), and titanium silicate (TS-1)) were used on screen-printed films of $\mathrm{WO}_{3}$ and $\operatorname{In}_{2} \mathrm{O}_{3}$ on alumina substrates of $3 \times 3 \mathrm{~mm}^{2}$ with gold electrodes and a platinum heater [46]. H-ZSM-5 zeolite was synthesized by thermally treating a powder of NH4-ZSM-5 at $100{ }^{\circ} \mathrm{C}$ for $8 \mathrm{~h}$ to remove first humidity and then, at $500{ }^{\circ} \mathrm{C}$ for $12 \mathrm{~h}$, to eliminate ammonia. The inks were obtained by mixing the pure powders $\left(\mathrm{In}_{2} \mathrm{O}_{3}, \mathrm{WO}_{3}, \mathrm{TS} 1\right.$ e H-ZSM) with an organic solvent (ESL-400, Agmet Ltd., King of Prussia, PA, USA) (Table 5). Some sensors were made by mixing the $\mathrm{In}_{2} \mathrm{O}_{3}$ powder with the two zeolites (30\%) (Table 5, Figure 15).


Figure 15. SEM micrographs of: (a) W.5; (b) In.5 ; (c)W.5.TS1.2; (d) In.5.TS1.2; (e) In.5.ZSM.2; (f) In + TS1.5; (g) In + ZSM.5; (h) blank sensor substrate. Reprinted with permission from Ref. [46]. 
Table 5. Investigated compositions [46], (number in parentheses indicates the number of layers).

\begin{tabular}{ccc}
\hline Sensor & Metal Oxide & Overlay \\
\hline W.5 & $\mathrm{WO}_{3}(5)$ & $\mathrm{Nil}$ \\
\hline In.5 & $\mathrm{In}_{2} \mathrm{O}_{3}(5)$ & $\mathrm{Nil}$ \\
\hline W.5.TS1.2 & $\mathrm{WO}_{3}(5)$ & $\mathrm{TS}-1(2)$ \\
\hline In.5.TS1.2 & $\mathrm{In}_{2} \mathrm{O}_{3}(5)$ & $\mathrm{TS}-1(2)$ \\
\hline In.5.ZSM.2 & $\mathrm{In}_{2} \mathrm{O}_{3}(5)$ & $\mathrm{H}-\mathrm{ZSM}-5(2)$ \\
\hline In+TS1.5 & $\mathrm{In}_{2} \mathrm{O}_{3}, 30 \%$ TS-1 (5) & Nil \\
\hline In+ZSM.5 & $\mathrm{In}_{2} \mathrm{O}_{3}, 30 \%$ H-ZSM-5 (5) & Nil \\
\hline
\end{tabular}

After screen printing each single layer, the films were dried for $10 \mathrm{~min}$ by means of an infrared lamp and heated at $600{ }^{\circ} \mathrm{C}$ for $1 \mathrm{~h}$. SEM observations revealed a film thickness of about $75 \mu \mathrm{m}$.

The sensors were tested at $350^{\circ}, 400^{\circ}$, and $500^{\circ} \mathrm{C}$ under a flow of $1000 \mathrm{~cm}^{3} / \mathrm{min}$ of $\mathrm{NO}_{2}(1 \mathrm{ppm})$, $\mathrm{NH}_{3}$ (50 ppm), or ethanol (EtOH, $100 \mathrm{ppm}$ ). Vapors of DMNB (2,3-dimethyl-2,3-dinitrobutane, $3 \mathrm{ppm}$ ), dinitromethane (MeNO2, $5000 \mathrm{ppm}$ ) and 2-ethylhexanol (296 ppm) were obtained from an air flow sent over the solid. Vapor pressure at $25^{\circ} \mathrm{C}$ and $1 \mathrm{~atm}$ were assumed to calculate the experimental explosive vapor concentration.

The sensors' response was determined according to Equation (8) for oxidizing gases:

$$
S=\frac{R}{R_{0}}
$$

and according to Equation (9) for reducing gases:

$$
S=\frac{R_{0}}{R}
$$

where $R_{0}$ and $R$ are the values of the sensor's resistance under air and under gas vapor, respectively.

The sensors were kept for $30 \mathrm{~min}$ under pure air flow before being in contact for $600 \mathrm{~s}$ with the gas analyte. Then, the surface was regenerated for $900 \mathrm{~s}$. The measurements were conducted either under dry air or under air and $50 \% \mathrm{RH}$.

Except for $\mathrm{NO}_{2}$, all the tested gases were reducing ones, thus the sensors' resistance decreased during the experiments. The optimum temperature was $350{ }^{\circ} \mathrm{C}$, and the sensor response decreased with the increase in the working temperature, except with ammonia and ethanol (Figure 16).

The sensors based on pure $\mathrm{WO}_{3}$ and TS-1 zeolite appeared to be the most sensitive to $\mathrm{NO}_{2}$ (Figure 16). For low 2-ethylhexanol concentrations, the films of $\operatorname{In}_{2} \mathrm{O}_{3}+\mathrm{TS}-1$ (30\%) were the most sensitive. However, pure indium oxide and pure tungsten oxide films showed higher responses to higher gas concentrations (Figure 17). The best results with DMNB were obtained with the pure $\operatorname{In}_{2} \mathrm{O}_{3}$ and the zeolite H-ZSM-5 (30\%) sensors, but the response was only slightly dependent on the gas concentration (Figure 18). The best results with nitromethane were reached by the pure $\operatorname{In}_{2} \mathrm{O}_{3}$ and the zeolite H-ZSM-5 (30\%) sensors.

To conclude, H-ZSM-5 zeolite demonstrated improved sensor responses to nitro-group containing materials and $\mathrm{WO}_{3}$ had good stability to humidity, and as reported in the literature, was very sensitive to $\mathrm{NO}_{2}$ gas. 


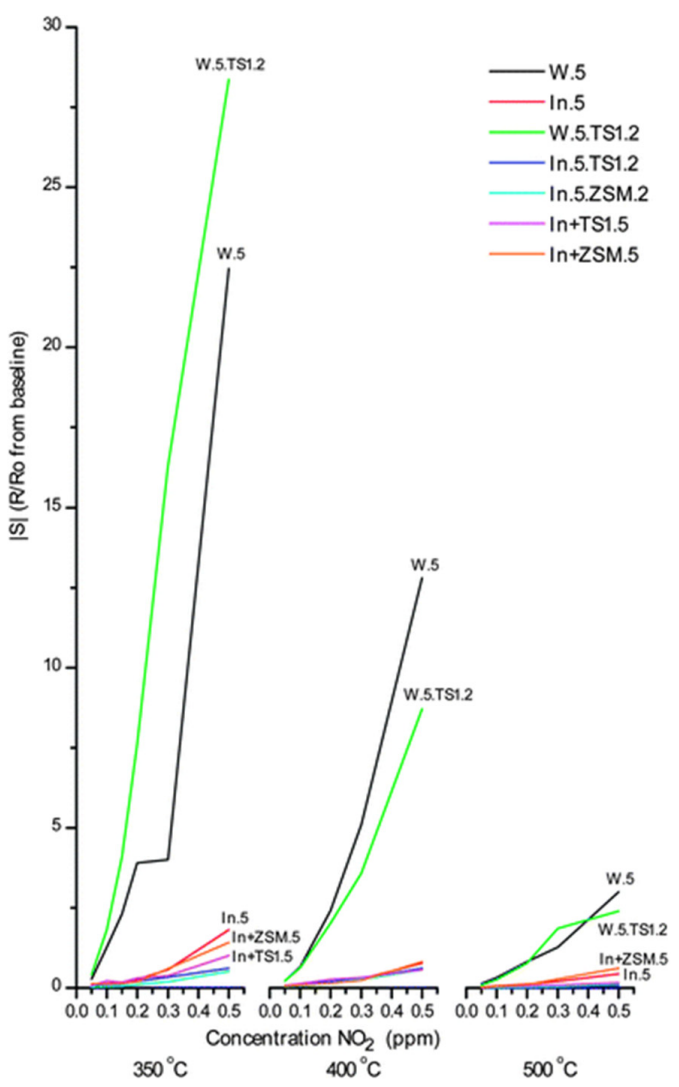

Figure 16. Sensors' response under $\mathrm{NO}_{2}(0.05-0.5 \mathrm{ppm})$ at $350{ }^{\circ} \mathrm{C}, 400{ }^{\circ} \mathrm{C}$, and $500{ }^{\circ} \mathrm{C}$ in dry air. Reprinted with permission from Ref. [46].

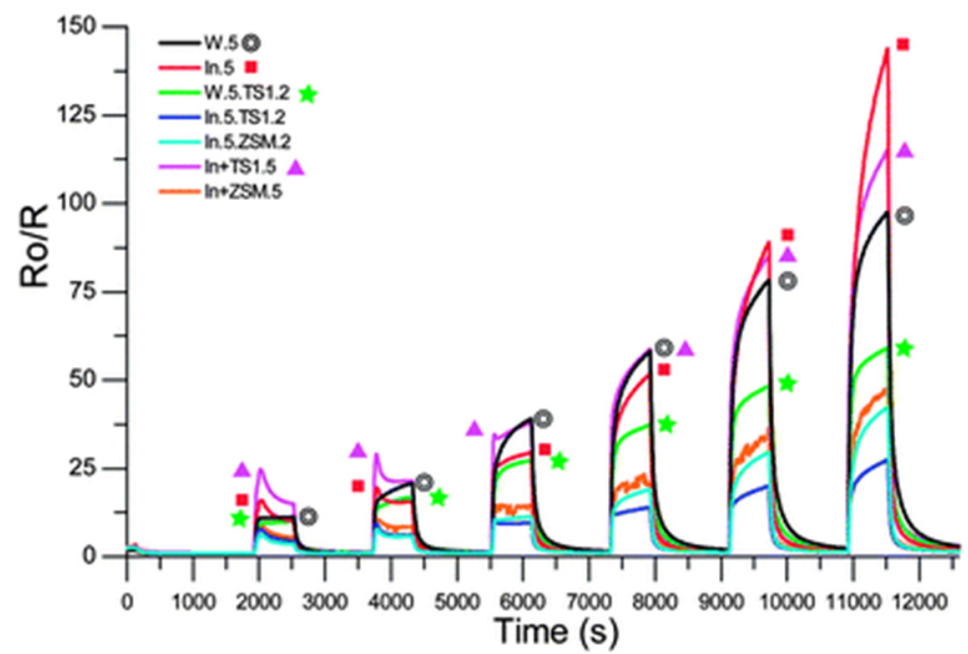

Figure 17. Sensors' response under 2-ethylhexanol (ca. 15, 30, 59, 89, 118, and 148 ppm) at $400{ }^{\circ} \mathrm{C}$ under dry air. Reprinted with permission from Ref. [46]. 




Figure 18. Sensors' response under DMNB (4 different concentrations starting at about $1.5 \mathrm{ppm}$ ) at $350{ }^{\circ} \mathrm{C}$ in dry air. Reprinted with permission from Ref. [46].

MOFs are extended crystalline structures wherein metal cations or clusters of cations ("nodes") are connected by organic "struts" or "linkers" ions or molecules. The variety of metal ions, organic linkers, and structural figures leads to an essentially infinite number of possible combinations [47]. MOFs are often compared to zeolites for their large internal specific surface areas, extensive porosity, and high degree of crystallinity. Therefore, MOFs and zeolites have been utilized for many of the same applications such as gas storage and separation as well as heterogeneous catalysis and gas sensors [47,48]. To this aim, ZIF-8-based nanocomposite membranes (Zeolitic Imidazolate Frameworks) were recently developed [28]. The method involves the atomic layer deposition (ALD) of ZnO nanowires (NWs) and their subsequent conversion to ZIF-8 using a 2-methylimidazole/methanol solution under solvothermal conditions at $100{ }^{\circ} \mathrm{C}$ for $24 \mathrm{~h}$, leading to the coverage of $\mathrm{ZnO}$ nanowires with a thin ZIF-8 molecular sieve membrane. ZIFs structures represent a subfamily of Metal-Organic Frameworks (MOFs) having ultrahigh porosity, structural, and chemical tunability together with structural flexibility and huge equivalent internal specific surface area [28]. The optimized $\mathrm{ZnO}$ ZIF-8-based nanocomposite sensors showed a selective response at $300{ }^{\circ} \mathrm{C}$ to $\mathrm{H}_{2}$, in comparison with the pristine $\mathrm{ZnO}$ nanowires sensor, while showing negligible responses to $\mathrm{C}_{7} \mathrm{H}_{8}$ and $\mathrm{C}_{6} \mathrm{H}_{6}$. Although these sensors were not directly evaluated with respect to explosive vapors, the proposed strategy is rather promising to increase the selectivity of SMOs.

\section{3. $\mathrm{WO}_{3}$ Composites}

$\mathrm{WO}_{3}-\mathrm{Cr}_{1.65} \mathrm{Ti}_{0.35} \mathrm{O}_{3}\left(\mathrm{WO}_{3}-\mathrm{CTO}\right)$ composites were prepared from $\mathrm{WO}_{3}, \mathrm{Cr}_{2} \mathrm{O}_{3}$, and $\mathrm{TiO}_{2}$ powders via a solid route and thermal treatment at $900{ }^{\circ} \mathrm{C}$ for $12 \mathrm{~h}$ [32]. The metal oxide paste was then screen-printed onto gold interdigitated patterned electrodes on $3 \times 3 \mathrm{~mm}^{2}$ alumina substrates. After drying, the sensors were fired at $600{ }^{\circ} \mathrm{C}$ for $1 \mathrm{~h}$. Table 6 displays the investigated sensors.

Table 6. Investigated compositions [32].

\begin{tabular}{cc}
\hline Sensor Abbreviation & Metal Oxide (4 Layers) \\
\hline $\mathrm{WO}_{3}$ & $\mathrm{WO}_{3} 100 \%$ \\
\hline $\mathrm{CTO}$ & Chromium titanium oxide (100\%) \\
\hline $2 \mathrm{~L} \mathrm{WO}_{3}$ & 2 layers of $\mathrm{WO}_{3}$ over 2 layers of $\mathrm{CTO}$ \\
\hline $2 \mathrm{~L} \mathrm{CTO}$ & 2 layers of $\mathrm{CTO}_{\text {over } 2 \text { layers of } \mathrm{WO}_{3}}$ \\
\hline $75 \% \mathrm{WO}_{3}$ & $75 \% \mathrm{WO}_{3}, 25 \% \mathrm{CTO}$ \\
\hline $75 \% \mathrm{CTO}$ & $75 \% \mathrm{CTO}_{2} 25 \% \mathrm{WO}_{3}$ \\
\hline $50 / 50$ & $50 \% \mathrm{CTO}, 50 \% \mathrm{WO}_{3}$ \\
\hline
\end{tabular}


The sensors were exposed to four test gases (ethanol, ammonia, nitromethane, and nitrogen dioxide) associated with explosives at $300{ }^{\circ} \mathrm{C}, 400{ }^{\circ} \mathrm{C}$, and $500{ }^{\circ} \mathrm{C}$. The concentration of the gases used were $10 \%, 20 \%, 40 \%, 80 \%$, and $100 \%$ of their source concentration (100 ppm for ethanol, $50 \mathrm{ppm}$ for ammonia, and $7200 \mathrm{ppm}$ for nitromethane (NM)). On the contrary, the concentration of nitrogen dioxide was $5 \%, 10 \%, 20 \%, 40 \%$, and $50 \%$ of its source concentration ( $200 \mathrm{ppm}$ ). The sensor's response (S) was calculated according to Equations (8) and (9), respectively, for oxidizing and reducing gases.

Currently a single sensor did not have the selectivity required for the detection of explosives; however, by using an array made of these seven sensors, the selectivity of explosive vapors among the investigated gases is possible. Both composites sensors and 2-layered SMOs showed higher responses to target gases with respect to pristine sensing materials due to the presence of $n-p$ heterojunctions (Figure 19).

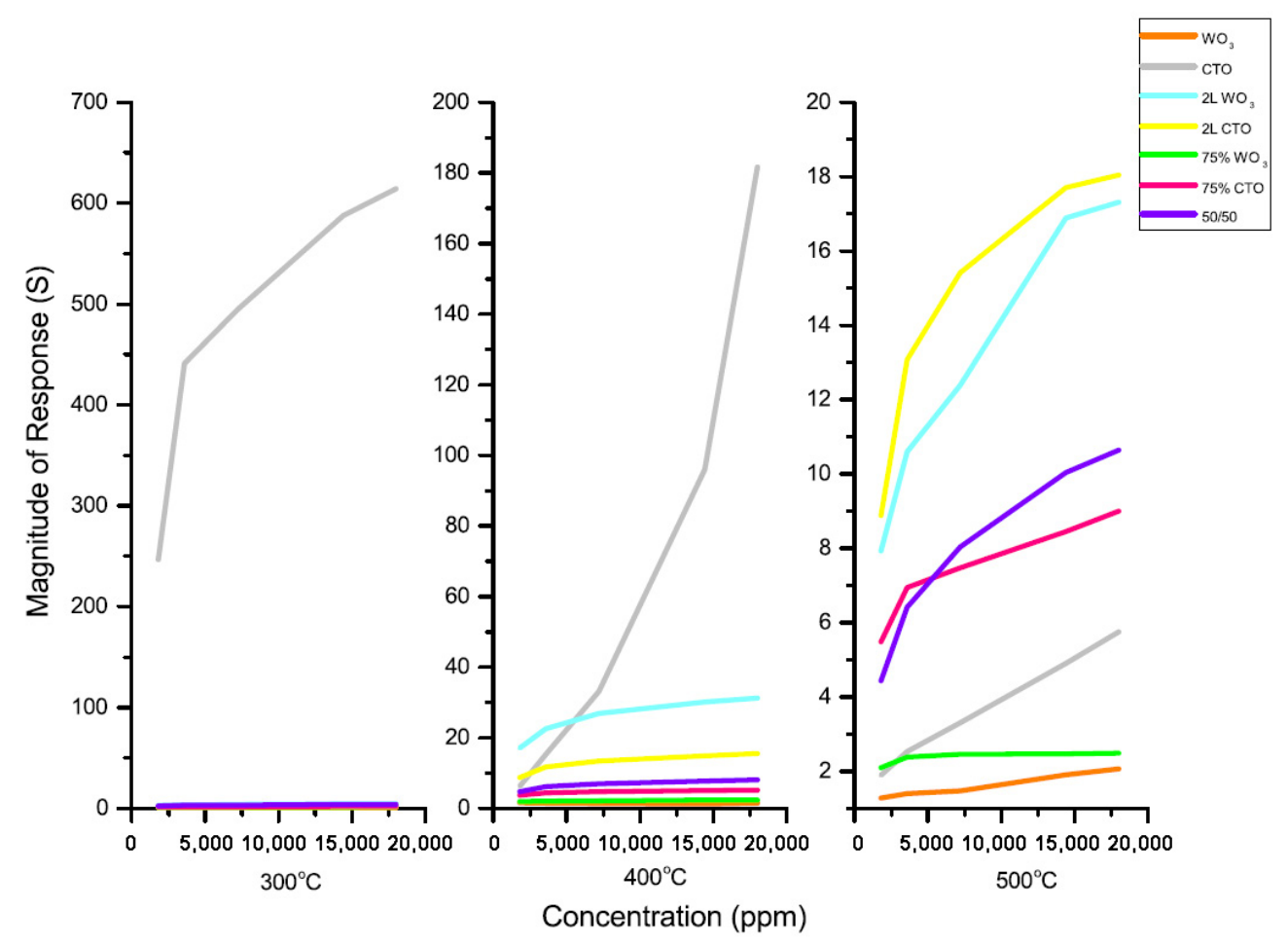

Figure 19. Sensor response for an array of sensors exposed to $\mathrm{NM}$ at $300{ }^{\circ} \mathrm{C}, 400{ }^{\circ} \mathrm{C}$, and $500{ }^{\circ} \mathrm{C}$. Reprinted with permission from Ref. [32].

\section{Conclusions}

Outstanding progress has been made in the development of metal oxide gas sensors in the last decades, and it has been demonstrated that the use of nanocomposites in the development of conductometric metal oxide gas sensors for explosives detection is possible, and under optimal compositions, certain parameters of sensors can be effectively improved.

The incorporation of a second phase component in the sensor material, either as second metal oxide or as precious metal nanoparticles, can improve sensitivity by limiting crystallite/grain growth of the principal phase (and thus maintaining a high surface area), by adding a catalytic function and by exercising a favorable influence on the near-surface band structure. Close control of microstructure of both single oxides and of materials combinations can also greatly increase sensitivity. However, a persistent challenge still has to be solved: the interference from, and/or the degradation of gas responses by humidity [49]. As conductometric sensors offer attractive opportunities for addressing the urgent demands for innovative miniaturized devices for on-site detection of explosive materials at a cost that is much lower than current technologies, this drawback must be overcome. 
To this aim, for example, experimental results showed that $\mathrm{TiO}_{2}$ nanowires had a significant reduction of cross-sensitivity to water vapor under UV illumination while the response to TNT showed a moderate increase. Photocatalytic oxidation of water molecules on the surface of $\mathrm{TiO}_{2}$ nanowires under UV illumination can be used to increase surface hydroxyl groups that eliminate the cross-sensitivity of the nanowires toward ambient humidity while maintaining a stable response to explosives [50].

Another possible solution to increase the selectivity of SMOs is the use of a catalytic filter on top of them [51,52]. The action of a gas filter may be two-fold: it aims at hindering the interfering gas from reaching the detection substrate, and at the same time, allowing the target gas to reach the sensor surface, and to transform the gas mixture to be detected into a mixture which increases the detection of the target gas.

Author Contributions: This paper is to be attributed in equal parts to the authors.

Funding: This research received no external funding.

Acknowledgments: Acknowledgements going to anonymous Reviewers who have contributed with their suggestions and comments to improve the quality of this paper, to Academic Editors and to all people of the MDPI structures for their valuable work.

Conflicts of Interest: The authors declare no conflict of interest.

\section{References}

1. Yang, R.; Wei, Y.; Yu, Y.; Gao, C.; Wang, L.; Liu, J.-H.; Huang, X.-J. Make it different: The plasma treated multi-walled carbon nanotubes improve electrochemical performances toward nitroaromatic compounds. Electrochim. Acta 2012, 76, 354-362. [CrossRef]

2. Kaplan, D.L.; Kaplan, A.M. 2,4,6-Trinitrotoluene-Surfactant Complexes: Decomposition, Mutagenicity, and Soil Leaching Studies. Environ. Sci. Technol. 1982, 16, 566-571. [CrossRef] [PubMed]

3. Roberts, W.C.; Commons, B.J.; Bausum, H.T.; Abemathy, C.O.; Murphy, J.J.; Khanna, K.; Ohanian, E.V. Overview of the Health Effects of Selected Munitions Chemicals. Available online: https:/ / nepis.epa.gov/Exe/ZyNET.exe/20003MXC.TXT?ZyActionD=ZyDocument\&Client=EPA\& Index $=1991+$ Thru $+1994 \&$ Docs $=\& Q u e r y=\&$ Time $=\&$ EndTime $=\&$ SearchMethod $=1 \&$ TocRestrict $=$ $\mathrm{n} \& T o c=\&$ TocEntry $=\& Q$ Field $=\& Q$ Field Year $=\& Q$ FieldMonth $=\& Q$ FieldDay $=\& I n t Q F i e l d O p=0 \&$ ExtQFieldOp=0\&XmlQuery=\&File=D\%3A\%5Czyfiles\%5CIndex\%20Data\%5C91thru94\%5CTxt\% 5C00000007\%5C20003MXC.txt\&User=ANONYMOUS\&Password $=$ anonymous\&SortMethod $=\mathrm{h} \%$ 7C-\&MaximumDocuments=1\&FuzzyDegree=0\&ImageQuality=r75g8/r75g8/x150y150g16/i425\& Display $=$ hpfr\&DefSeekPage $=x \& S e a r c h B a c k=Z y$ ActionL\&Back $=Z y$ ActionS\&BackDesc $=$ Results\%20page\& MaximumPages $=1 \& Z y$ Entry $=1 \& S e e k P a g e=x \& Z y P U R L$ (accessed on 10 June 2018).

4. Strle, D.; Štefane, B.; Nahtigal, U.; Zupanič, E.; Pozgan, F.; Kvasič, I.; Maček, M.; Trontelj, J.; Muševič, I. Surface-Functionalized COMB Capacitive Sensors and CMOS Electronics for Vapor Trace Detection of Explosives. IEEE Sens. J 2012, 12, 1048-1057. [CrossRef]

5. Bielecki, Z.; Janucki, J.; Kawalec, A.; Mikołajczyk, J.; Pałka, N.; Pasternak, M.; Pustelny, T.; Stacewicz, T.; Wojtas, J. Sensors and systems for the detection of explosive devices - An overview. Metrol. Meas. Syst. 2012, 19, 3-28. [CrossRef]

6. Ewing, R.G.; Waltman, M.J.; Atkinson, D.A.; Grate, J.W.; Hotchkiss, P.J. The vapor pressures of explosives. Trends Anal. Chem. 2013, 42, 35-48. [CrossRef]

7. Östmark, H.; Wallin, S.; Ang, H.G. Vapor Pressure of Explosives: A Critical Review. Propellants Explos. Pyrotech. 2012, 37, 12-23. [CrossRef]

8. Sekhar, P.K.; Wignes, F. Trace detection of research department explosive (RDX) using electrochemical gas sensor. Sens. Actuators B Chem. 2016, 227, 185-190. [CrossRef]

9. Qu, J.; Ge, Y.; Zu, B.; Li, Y.; Dou, X. Transition-Metal-Doped p-Type ZnO Nanoparticle-Based Sensory Array for Instant Discrimination of Explosive Vapors. Small 2016, 12, 1-9. [CrossRef] [PubMed]

10. Müller, G.; Hackner, A.; Beer, S.; Göbel, J. Solid-State Gas Sensors: Sensor System Challenges in the Civil Security Domain. Materials 2016, 9, 65. [CrossRef] [PubMed]

11. Atkins, P.; Jones, L. Chimica Generale, Seconda Edizione Italiana; Zanichelli Editore: Bologna, Italy, 1998; p. 253. 
12. Dey, A. Semiconductor metal oxide gas sensors: A review. Mater. Sci. Eng. B 2018, 229, 206-217. [CrossRef]

13. Yamazoe, N.; Shimanoe, K. Receptor function of small semiconductor crystals with clean and electron-traps dispersed surfaces. Thin Solid Films 2009, 517, 6148-6155. [CrossRef]

14. Korotcenkov, G.; Cho, B.K. Metal oxide composites in conductometric gas sensors: Achievements and challenges. Sens. Actuators B Chem. 2017, 244, 182-210. [CrossRef]

15. Korotcenkov, G.; Brinzari, V.; Pronin, I.A.; Ham, M.H.; Cho, B.K. Metal Oxides for Application in Conductometric Gas Sensors: How to Choose? Solid State Phenom. 2017, 266, 187-195. [CrossRef]

16. Bârsan, N.; Weimar, U. Conduction Model of Metal Oxide Gas Sensors. J. Electroceram. 2001, 7, $143-167$. [CrossRef]

17. Göpel, W.; Schierbaum, K.D. $\mathrm{SnO}_{2}$ sensors: Current status and future prospects. Sens. Actuators B Chem. 1995, 26-27, 1-12. [CrossRef]

18. Sun, Y.-F.; Liu, S.-B.; Meng, F.-B.; Liu, J.-Y.; Jin, Z.; Kong, L.-T.; Liu, J.-H. Metal Oxide Nanostructures and Their Gas Sensing Properties: A Review. Sensors 2012, 12, 2610-2631. [CrossRef] [PubMed]

19. Yamazoe, N.; Shimanoe, K. Receptor Function and Response of Semiconductor Gas Sensor. J. Sens. 2009, 875704. [CrossRef]

20. Xu, C.; Tamaki, J.; Miura, N.; Yamazoe, N. Grain size effects on gas sensitivity of porous $\mathrm{SnO}_{2}$-based elements. Sens. Actuators B Chem. 1991, 3, 147-155. [CrossRef]

21. Bârsan, N.; Schweizer-Berberich, M.; Göpel, W. Fundamental and practical aspects in the design of nanoscaled $\mathrm{SnO}_{2}$ gas sensors: A status report. Fresenius J. Anal. Chem. 1999, 365, 287-304. [CrossRef]

22. Oprea, I.A.; Bârsan, N.; Weimar, U. Work function changes in gas sensitive materials: Fundamentals and applications. Sens. Actuators B Chem. 2009, 142, 470-493. [CrossRef]

23. Kim, H.-J.; Lee, J.-H. Highly sensitive and selective gas sensors using p-type oxide semiconductors: Overview. Sens. Actuators B Chem. 2014, 192, 607-627. [CrossRef]

24. Hübner, M.; Simion, C.E.; Tomescu-Stănoiu, A.; Pokhrel, S.; Bârsan, N.; Weimar, U. Influence of humidity on $\mathrm{CO}$ sensing with p-type $\mathrm{CuO}$ thick film gas sensors. Sens. Actuators B Chem. 2011, 153, 347-353. [CrossRef]

25. Brattain, W.H.; Bardeen, J. Surface Properties of Germanium. Bell Syst. Tech. J. 1953, 32, 1-41. [CrossRef]

26. Seiyama, T.; Kato, A.; Fujushi, K.; Nagatani, M. A new detector for gaseous components using semiconductive thin films. Anal. Chem. 1962, 34, 1502-1503. [CrossRef]

27. Gas Sensors Market by Gas Type (Oxygen, Carbon Monoxide, Carbon Dioxide, Ammonia, Chlorine, Hydrogen Sulfide, Nitrogen Oxide, Volatile organic Compounds, Hydrocarbons), Technology, End-Use Application, Geography—Global Forecast 2023. Available online: https:/ /www.marketsandmarkets.com/Market-Reports / gas-sensor-market-245141093.html?gclid=EAIaIQobChMI5Lb-jtLI2wIVlIRwCh3teAkOEAAYASAAEgKT7_ D_BwE (accessed on 10 June 2018).

28. Drobek, M.; Kim, J.-H.; Bechelany, M.; Vallicari, C.; Julbe, A.; Kim, S.S. MOF-Based Membrane Encapsulated ZnO Nanowires for Enhanced Gas Sensor Selectivity. ACS Appl. Mater. Interfaces 2016, 8, 8323-8328. [CrossRef] [PubMed]

29. Korotcenkov, G. Metal oxides for solid-state gas sensors: What determines our choice? Mater. Sci. Eng. B 2007, 139, 1-23. [CrossRef]

30. Doll, T.; Eisele, I. Gas detection with work function sensors. Proc. SPIE 1998, 3539. [CrossRef]

31. Korotcenkov, G.; Brinzari, V.; Boris, Y.; Ivanov, M.; Schwank, J.; Morante, J. Influence of surface Pd doping on gas sensing characteristics of $\mathrm{SnO}_{2}$ thin films deposited by spray pirolysis. Thin Solid Films 2003, 436, 119-126. [CrossRef]

32. Horsfall, L.A.; Pugh, D.C.; Blackman, C.S.; Parkin, I.P. An array of $\mathrm{WO}_{3}$ and CTO heterojunction semiconducting metal oxide gas sensors used as a tool for explosive detection. J. Mater. Chem. A 2017, 5, 2172-2179. [CrossRef]

33. Yamazoe, N.; Kurokawa, Y.; Seiyama, T. Effects of additives on semiconductor gas sensors. Sens. Actuators 1983, 4, 283-289. [CrossRef]

34. Korotcenkov, G. Gas response control through structural and chemical modification of metal oxide films: State of the art and approaches. Sens. Actuators B Chem. 2005, 107, 209-232. [CrossRef]

35. Makimoto, O.; Arakawa, T. Sensing properties of $\mathrm{Ln}_{2} \mathrm{CuO}_{4}-\mathrm{SnO}_{2}$, ( $\mathrm{Ln}=$ rare earth) having a heterojunction. Sens. Actuators B 1993, 13-14, 585-586. [CrossRef]

36. Marichy, C.; Pinna, N. Atomic Layer Deposition to Materials for Gas Sensing Applications. Adv. Mater. Interfaces 2016, 3, 1-20. [CrossRef] 
37. Cabot, A.; Arbiol, J.; Morante, J.R.; Weimar, U.; Bârsan, N.; Göpel, W. Analysis of the noble metal catalytic additives introduced by impregnation of as obtained $\mathrm{SnO}_{2}$ sol-gel nanocrystals for gas sensors. Sens. Actuators B Chem. 2000, 70, 87-100. [CrossRef]

38. Korotcenkov, G.; Brinzari, V.; Cho, B.K. Conductometric gas sensors based on metal oxides modified with gold nanoparticles: A review. Microchim. Acta 2016, 183, 1033-1054. [CrossRef]

39. Marikutsa, A.V.; Rumyantseva, M.N.; Gaskov, A.M.; Samoylov, A.M. Nanocrystalline Tin Dioxide: Basics in Relation with Gas Sensing Phenomena Part II. Active Centers and Sensor Behavior. Inorg. Mater. 2016, 52, 1311-1338. [CrossRef]

40. Korotcenkov, G.; Han, S.-D.; Cho, B.K.; Brinzari, V. Grain Size Effects in Sensor Response of Nanostructured $\mathrm{SnO}_{2}$ - and $\mathrm{In}_{2} \mathrm{O}_{3}$-Based Conductometric. Thin Film Gas Sensor. Crit. Rev. Solid State Mater. Sci. 2009, 34, 1-17. [CrossRef]

41. Rumyantseva, M.N.; Gas'kov, A.M. Chemical modification of nanocrystalline metal oxides: Effect of the real structure and surface chemistry on the sensor properties. Russ. Chem. Bull. Int. Ed. 2008, 57, 1106-1125. [CrossRef]

42. Zhu, L.; Zeng, W. Room-temperature gas sensing of ZnO-based gas sensor: A review. Sens. Actuators A-Phys. 2017, 267, 242-261. [CrossRef]

43. Dobrokhotov, V.; Oakes, L.; Sowell, D.; Larin, A.; Hall, J.; Kengne, A.; Bakharev, P.L.; Corti, G.; Cantrell, T.; Prakash, T.; et al. Toward the nanospring-based artificial olfactory system for trace-detection of flammable and explosive vapors. Sens. Actuators B Chem. 2012, 168, 138-148. [CrossRef]

44. Guo, L.; Yang, Z.; Li, Y.; Zu, B.; Dou, X. Sensitive, real-time and anti-interfering detection of nitro-explosive vapors realized by $\mathrm{ZnO} / \mathrm{rGO}$ core/shell micro-Schottky junction. Sens. Actuators B Chem. 2017, 239, $286-294$. [CrossRef]

45. Gui, Y.; Xie, C.; Xu, J.; Wang, G. Detection and discrimination of low concentration explosives using MOS nanoparticle sensors. J. Hazard. Mater. 2009, 164, 1030-1035. [CrossRef] [PubMed]

46. Peveler, W.J.; Binions, R.; Hailes, S.M.V.; Parkin, I.P. Detection of explosive markers using zeolite modified gas sensors. J. Mater. Chem. A 2013, 1, 2613-2620. [CrossRef]

47. Kreno, L.E.; Leong, K.; Farha, O.K.; Allendorf, M.; Van Duyne, R.P.; Hupp, J.T. MetalOrganic Framework Materials as Chemical Sensors. Chem. Rev. 2012, 112, 1105-1125. [CrossRef] [PubMed]

48. Kumar, P.; Deep, A.; Kim, K.-H. Metal organic frameworks for sensing applications. Trends Anal. Chem. 2015, 73, 39-53. [CrossRef]

49. Moseley, P.T. Progress in the development of semiconducting metal oxide gas sensors: A review. Meas. Sci. Technol. 2018, 28, 082001. [CrossRef]

50. Wang, D.; Chen, A.; Jen, A.K.-Y. Reducing cross-sensitivity of $\mathrm{TiO}_{2}-(\mathrm{B})$ nanowires to humidity using ultraviolet illumination for trace explosive detection. Phys. Chem. Chem. Phys. 2013, 15, 5017-5021. [CrossRef] [PubMed]

51. Fleischer, M.; Kornely, S.; Weh, T.; Frank, J.; Meixner, H. Selective gas detection with high-temperature operated metal oxides using catalytic filters. Sens. Actuators B Chem. 2000, 69, 205-210. [CrossRef]

52. Tulliani, J.M.; Moggi, P. Development of a porous layer catalytically activated for improving gas sensors performances. Ceram. Int. 2007, 33, 1199-1203. [CrossRef]

(C) 2018 by the authors. Licensee MDPI, Basel, Switzerland. This article is an open access article distributed under the terms and conditions of the Creative Commons Attribution (CC BY) license (http://creativecommons.org/licenses/by/4.0/). 